This item was submitted to Loughborough's Research Repository by the author.

Items in Figshare are protected by copyright, with all rights reserved, unless otherwise indicated.

\title{
Dust generation on a proglacial floodplain, West Greenland
}

PLEASE CITE THE PUBLISHED VERSION

http://www.sciencedirect.com/science/article/pii/S187596371100005X

PUBLISHER

(c) Elsevier

VERSION

AM (Accepted Manuscript)

LICENCE

CC BY-NC-ND 4.0

REPOSITORY RECORD

Bullard, Joanna E., and Martin J. Austin. 2019. "Dust Generation on a Proglacial Floodplain, West Greenland". figshare. https://hdl.handle.net/2134/8080. 
This item was submitted to Loughborough's Institutional Repository (https://dspace.lboro.ac.uk/) by the author and is made available under the following Creative Commons Licence conditions.

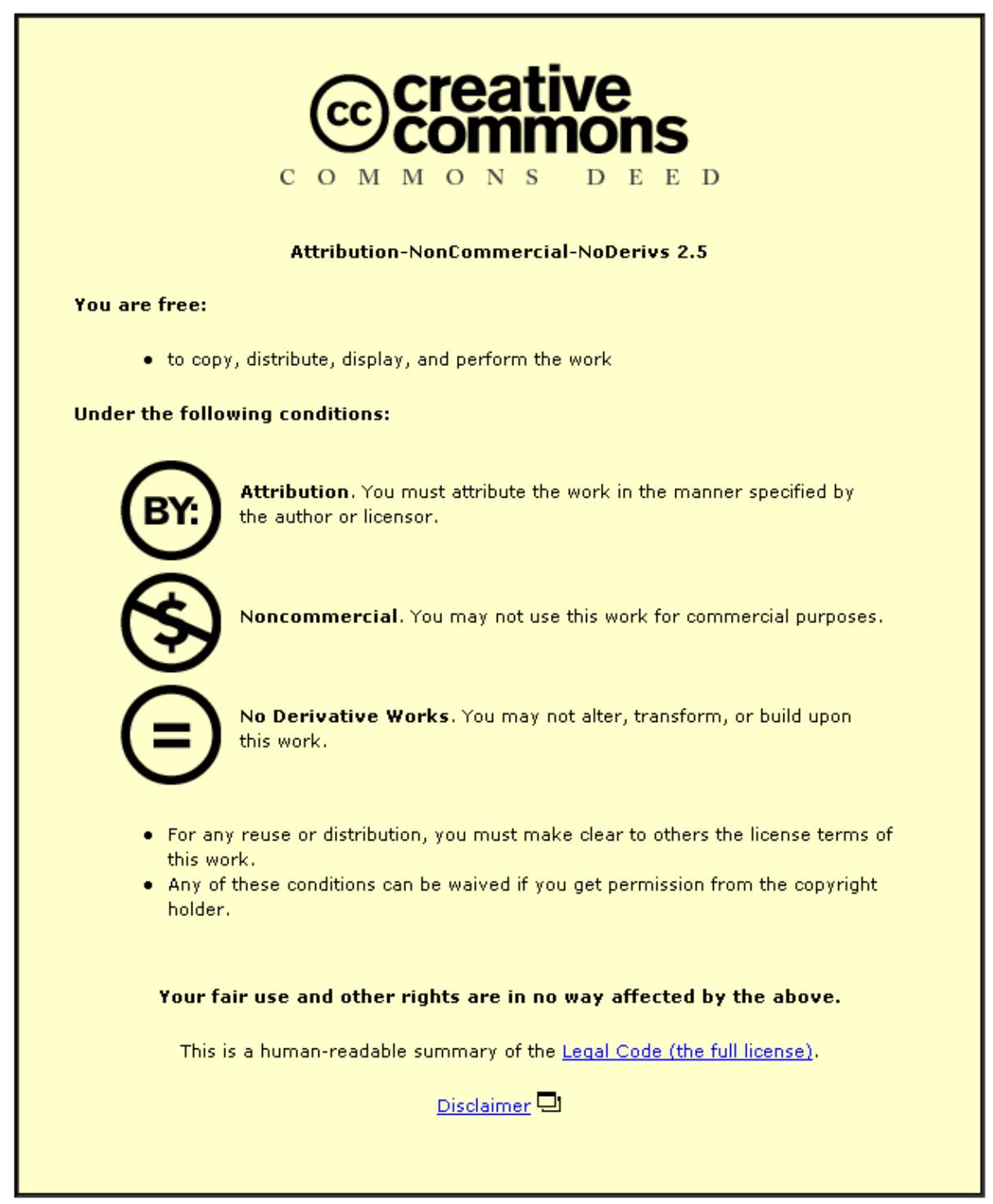

For the full text of this licence, please go to: http://creativecommons.org/licenses/by-nc-nd/2.5/ 
Dust generation on a proglacial floodplain, West Greenland

Joanna E. Bullard* and Martin J. Austin ${ }^{1}$

Department of Geography, Loughborough University, Leicestershire LE11 3TU UK j.e.bullard@lboro.ac.uk

${ }^{1}$ Present address: School of Marine Sciences and Engineering, University of Plymouth, Drake Circus, Plymouth, Devon, PL4 8AA UK martin.austin@plymouth.ac.uk

${ }^{*}$ Corresponding author 


\begin{abstract}
The interplay of glacial dynamics, glaciofluvial and aeolian transport in proglacial landscapes plays an important role in local environmental systems and in the global context by affecting the amount of dust generated and transported at different phases of glacial-interglacial cycles. Glacial outwash plains are a significant source of dust, however the processes involved in dust generation on proglacial floodplains are poorly documented. We report a study of the quantity and characteristics of aeolian suspended sediment transport in Sandflugtdalen, a valley containing a proglacial floodplain and aeolian dunefield in West Greenland. Although the surface sediment of both the floodplain and dunefield contain a considerable amount of sand-sized material, wind speeds recorded were insufficiently strong to mobilise this material; this is probably due to the armouring effect of coarser particles in the surface deposits. Nevertheless, fine (dust-sized) aeolian sediments were transported down valley in suspension and the source of this material was a silt-dominated meltwater deposit up valley from the monitoring sites. Dust transport ranged from 0.0008-0.082 g m-w s-1 over seven days and 0.0035-0.011 g m-w s-1 over a further 57 days during which no additional fluvial sediments were deposited. The reduction in sediment transport rate is attributed to both a depleted sediment supply and a decrease in above threshold winds. The supply of fine sediments to this proglacial region is dependent on meltwater suspended sediment loads which are predicted to increase during glacier retreat; reworking of the floodplain during ice retreat may also make more material available for aeolian transport.
\end{abstract}

Keywords: proglacial floodplain, dust, aeolian transport, Greenland 


\section{Introduction}

A strong coupling between dust and climate has been identified that is sustained through multiple glacial-interglacial cycles (e.g. Lambert et al. 2008). The interplay of glacial dynamics, glaciofluvial and aeolian transport in proglacial landscapes plays an important role therefore, not only in local environmental systems, but also in the global context by affecting the amount of dust generated and transported. Glacial outwash plains have been cited as a significant source of dust in the southern hemisphere (e.g. Sugden et al. 2009) and must also have been important dust sources in the northern hemisphere. Cold climate aeolian processes and landforms are widely acknowledged in proglacial and paraglacial geomorphology (e.g. Ballantyne, 2002; Seppälä, 2004), but have received considerably less attention than aeolian processes in warm arid or temperate coastal regions. Under contemporary conditions, many high latitude or high altitude regions have limited rainfall (e.g. mean annual precipitation in the Dry Valleys of Antarctica is $<60 \mathrm{~mm}$ rainfall equivalent) including parts of the Andean altiplano, and some ice-free regions of the Arctic and Antarctic. Seppälä (2004) estimates that cold arid areas defined as those where the mean temperature of the warmest month is less than $10^{\circ} \mathrm{C}$ and mean annual precipitation is less than $250 \mathrm{~mm}$ - cover around 5 million $\mathrm{km}^{2}$. In addition, some humid, cold areas such as in New Zealand and Iceland have limited vegetation cover and sufficiently strong winds for aeolian processes to be important (e.g. Arnalds et al. 2001, McGowan \& Sturman, 1997, Marx \& McGowan, 2005). Glacierised catchments in these areas typically receive an abundance of fluvially-supplied sediment $<2000 \mu \mathrm{m}$ in diameter. Diurnal and seasonal discharge cycles lead to the deposition of these sands and silts across outwash plains where, following desiccation and in the absence of dense vegetation, they may be entrained by strong katabatic or density-driven downglacier winds or, in the proximity of ice sheets, by winds driven by steep regional or continental pressure gradients associated with persistent atmospheric high pressure.

The principles of aeolian sediment transport established in temperate (usually coastal) or sub-tropical regions also apply to cold climate regions. For a given set of grain characteristics, aeolian sediment transport is positively related to wind velocity and turbulence intensity, but negatively related to surface roughness and sediment 
moisture content. There are, however, differences between threshold wind velocities required to entrain particles under warm or cool conditions depending on air temperature, pressure and humidity all of which affect the density of the air (McKenna Neuman, 2004, Selby et al. 1974); for example for a given particle size threshold wind velocities are lowered in cold conditions and increase as temperature increases. Additional considerations in cold climates include the impacts of snow, frost and sublimation (Kurosaki \& Mikami, 2004, McKenna Neuman \& Gilbert, 1986). Thick snow cover can protect sediments from deflation and frost can cement fine particles preventing their erosion - alternatively, frost activity may enhance surface erodibility by breaking up aggregates and limiting plant growth.

Hobbs (1942) argued that wind was the most important agent of sediment transport within extramarginal zones to continental glaciers, and the effects of deflation and aeolian modification on proglacial landforms has been widely reported (e.g. Derbyshire \& Owen, 1996, Gisladottir, et al. 2005, Glasser \& Hambrey, 2002, Riezobos et al. 1986). There are, however, very few estimates of the quantity and characteristics of fine sediments deflated from proglacial areas. Exceptions include Nickling's (1978) study of aeolian sediment transport in the Kaskawulsh glacier

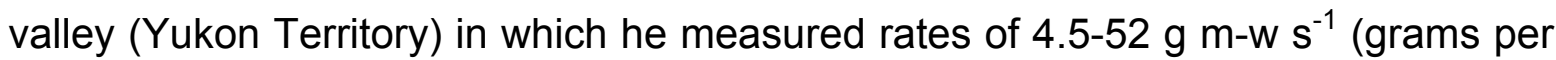
metre-width per second) for individual dust storm events, while in Iceland aeolian transport rates of $56 \mathrm{~g} \mathrm{m-W} \mathrm{s}{ }^{-1}$ for moderate storms on sand fields have been recorded (Arnalds et al. 2001). Church (1972) observed aeolian transport of $1600 \mathrm{~g}$ $\mathrm{m}-\mathrm{w}$ month $^{-1}$ on Baffin Island but $40 \%$ of this material was moved in one day. In addition to generating dust storms, aeolian sediments, when deposited, play an important role in proglacial geomorphology, notably as aeolian duneforms (Mountney \& Russell, 2009), inputs to soil development and as loess accumulations (Muhs et al. 2004).

Glacioaeolian deposits often reflect a complex pattern of reworking in proglacial areas where sediments are repeatedly eroded, transported and deposited by both wind and meltwater (e.g. Derbyshire \& Owen, 1996, Dijkmans \& Törnqvist, 1991). Understanding the processes determining the supply and availability of sediments therefore requires some consideration of both aeolian and fluvial systems and the ways in which they interact at a variety of scales (e.g. Bullard and Livingstone, 
2002, Field et al. 2009). In proglacial regions production and supply of suitable sediments is closely-linked to glacier and ice-sheet dynamics (such as ice velocity, sediment load and basal thermal conditions) and hydrology, relying on suspended sediments in meltwater being transported to proglacial areas before they can be entrained by the wind and further transported to distal regions. Climate-driven ice retreat is likely to result in increased mobilisation of material from long-term glacial sediment stores (Hodgkins et al., 2003, Jansson et al. 2005), delivering greater quantities of fine sediments to the floodplain than at present (assuming a proglacial lake does not form; Sugden et al. 2009). Moisture availability (meltwater, rain, snow, groundwater) has a significant impact on sediment availability as do the geomorphology, sedimentology and vegetation characteristics of the proglacial floodplain. For example, coarse lag deposits can prevent aeolian entrainment (e.g. Schwan, 1986) and vegetation cover can trap aeolian sediments, but is very limited on an active floodplain. Climate warming is likely to trigger more aeolian activity at glacial margins due to the degradation or burial of vegetation by aeolian sediments or more rapid desiccation of sediments by increased evaporation (Alho, 2003; Gisladottir et al. 2005). It is also known that locally-generated dust can play an important role in regulating ice albedo and the melting rate of glaciers and ice sheets (e.g. Adhikary et al. 2002, Oerlemans et al. 2009, Zdanowicz et al. 1998).

The aim of this paper is to examine the variability in surface characteristics and aeolian entrainment and transport across a proglacial floodplain. The experiment was conducted during the summer months with no snow or ice cover and started a few days after a meltwater flood event deposited fine sediments over large parts of the ice-proximal floodplain.

\section{Study Area}

Fieldwork was conducted between May and August 2007 in Sandflugtdalen, West Greenland (Figure 1). This proglacial valley extends from the head of Kangerlussuaq Fjord $\left(67^{\circ} 00^{\prime} \mathrm{N}, 50^{\circ} 43^{\prime} 20^{\prime \prime} \mathrm{W}\right)$ to the west margin of the Greenland Ice Sheet. It is representative of the Greenland coastal zone and geomorphic and stratigraphic mapping (Dijkmans and Törnqvist, 1991) have revealed extensive modern aeolian deposits, and indicate a close link between glacifluvial and aeolian activity. 
$<$ Figure 1>

Under modern conditions, the region has a continental subarctic climate regime with mean annual precipitation (1949-2003) of c.159 mm, very low runoff and mean annual temperature $-5.1^{\circ} \mathrm{C}$ (Aebly \& Fritz, 2009). Its location, $130 \mathrm{~km}$ from the coast, results in summer temperatures $>20^{\circ} \mathrm{C}$ (mean $9.4^{\circ} \mathrm{C}$ ) and a calculated mean annual evapotranspiration of c.300 mm. Consequently the area is very dry and receives little snow with, on average, over 150 snow-free and 80 consecutive frostfree days in summer. There is a bimodal wind regime dominated by katabatic winds from the east with less frequent westerly winds generated by Atlantic storms. Wind speeds are highest during winter months but decrease rapidly with increasing distance from the ice sheet (Dijkmans \& Törnqvist, 1991). The highest frequencies of winds $>10 \mathrm{~m} \mathrm{~s}^{-1}$ are in December and January, but Dijkmans \& Törnqvist, (1991) reported that $25 \%$ of winds can exceed $10 \mathrm{~m} \mathrm{~s}^{-1}$ in May and June.

There is essentially no direct aeolian input to the valley, although fine $(<4 \mu \mathrm{m})$ dust originating from Asia has been recorded in snow on the ice sheet and may constitute a very minor input (Steffensen, 1985). The principal source of fine sediment is material transported by suspension in glacial meltwater. Meltwater discharge records indicate several moderate-high magnitude summer flood events each year, with the potential to deposit fine material across the floodplain (Russell et al. 1995). Discharge from the Russell Glacier varies both seasonally and in response to periodic jökulhlaups and the damming of outflow drainage by periodic ice-front collapse (Mernild et al. 2008, Russell et al. 1995, Sugden et al. 1985). In 1987 a jökulhlaup distributed a layer of sediment "a few $\mathrm{cm}$ thick" across the floodplain, with a mean grain size of $40 \mu \mathrm{m}$, that was rapidly deflated (Dijkmans \& Törnqvist, 1991:10). Meltwater suspended sediment concentration is variable: Russell et al. (1995) reported a range of 100-4000 $\mathrm{mg} \mathrm{l}^{-1}$ from the Russell Glacier outlet; Friberg et al. (2001) measured 10-120 mg l-1 in July 1999 and in August 2006 the authors measured $480 \mathrm{mg} \mathrm{l}^{-1}$ at $15 \mathrm{~km}$ from the ice margin. Particle-size analysis of suspended meltwater sediments sampled $5 \mathrm{~km}$ from the ice sheet indicates that over $85 \%$ by volume of sediments were $<63 \mu \mathrm{m}$ in diameter, and particle-size modes occurred at approximately 1, 9, 27 and $50 \mu \mathrm{m}$ (Bullard et al. 2009). 
The eastern part of Sandflugtdalen has a broad valley floodplain in to which the Watson River is incised forming 5-10 m high terraces and aeolian sand is deposited in an almost continuous band along the northern fringe. The western part of the valley is contained in a narrow gorge and is largely devoid of aeolian deposits. Aeolian deposits at the eastern end of the valley include active and vegetationstabilised sand sheets, dunes up to $250 \mathrm{~m}$ above the floodplain, and extensive wind-blown silt deposits up to $0.7 \mathrm{~m}$ thick at higher altitudes (Dijkmans \& Törnqvist, 1991; Willemse et al. 2003). Whilst dune accumulation is closely associated with vegetation, the dune surfaces are active with a high percentage of bare, rippled sand and localised slipface formation (Figure 2). There is significant evidence of modern accumulation of aeolian sediments associated with roughness elements such as gravel bar deposits and localised vegetation on the floodplain and within the dunefields.

$<$ Figure 2>

\section{Methods}

\subsection{Instrumentation}

Five monitoring sites were established in a down valley transect. Site locations are shown in Figures 1 and 3 and described in Table 1 . The sites vary from a graveldominated fluvial system approximately $4.5 \mathrm{~km}$ from the ice front (site one) to a sand-dominated dunefield a further $4.2 \mathrm{~km}$ down valley (sites four and five). Vegetation cover is less than $10 \%$ at all sites. A reference station to monitor wind speed and direction was established at site three. This comprised Vector A-100R pulse-count rotating cup anemometers in a vertical array at heights of $0.18 \mathrm{~m}, 0.43$ $\mathrm{m}, 0.85 \mathrm{~m}, 1.5 \mathrm{~m}$ and $2.4 \mathrm{~m}$ and a Vector $\mathrm{W}-200 \mathrm{P}$ wind vane at $1.4 \mathrm{~m}$. It also included a thermistor at ground level, a soil moisture probe and Sensit H11B saltation impact sensor. Field data collection can be divided into two periods. During days 1-7 it was possible to visit the sites daily, during days 8-65 the sites were unattended. During days 1-7 a mobile monitoring array with the same instrumentation as the reference station (excluding the Sensit) was deployed at each site for periods $>20$ hours and the velocity profiles obtained were used to 
estimate aerodynamic roughness length $\left(z_{0}\right)$ (using the method of Bauer et al. 1992; Table 1). At each site wind speed was integrated over 15 second intervals for periods of 1 minute. Further analysis of the velocity data from the measurement arrays consisted of calculating the fractional speed-up ratio $(\delta s)$ as defined by Jackson \& Hunt (1975):

$$
\delta S=\left(u_{z}-U_{z}\right) / U_{z}
$$

where $u_{z}$ is the wind speed at height $z$ on the measurement array, and $U_{z}$ is the wind speed at height $z$ on the reference anemometer. The speed-up ratio allows an assessment of the changes in relative wind speed at each location. $A \delta s$ of +0.1 indicates an acceleration in velocity compared to the reference station at the same height of $10 \%$; a value of -0.1 indicates deceleration by $10 \%$. Hourly wind speed, direction, temperature data and rainfall (6 hourly) were also obtained from the weather station at Kangerlussuaq (WMO-ID 04231), located c.14 km west of site three at the head of the fjord (Carstensen \& Jørgensen, 2009). A comparison of data from Kangerlussuaq meteorological station and data from the reference station at site three (resampled to 10 minutes mean wind direction/speed each hour) for 6 12 June 2007 indicate that wind direction at the former is strongly bidirectional (resultant wind direction $267^{\circ}$ ) aligned with the fjord/valley orientation whereas site three (mean direction $258^{\circ}$ ) recorded a higher frequency and greater directional variability of down valley winds. This likely reflects the proximity of site three to the ice sheet and that the valley is broader and less topographically-constrained near the ice than at the head of the fjord. The overall range and magnitude of wind velocities at Kangerlussuaq is similar to that at site three but the diurnal pattern of velocities is very different which means the meteorological station records can not reliably be used as substitute for, or to extrapolate from, the field measurements. Temperature records at the two stations are similar with a minimum, mean and maximum at site three of $0.2^{\circ} \mathrm{C}, 12.2^{\circ} \mathrm{C}$ and $23.4^{\circ} \mathrm{C}$ respectively and at Kangerlussuaq meteorological station of $2.0^{\circ} \mathrm{C}, 11.3^{\circ} \mathrm{C}$ and $22.0^{\circ} \mathrm{C}$. The temperature records are closely correlated $\left(r^{2}=0.833, n=1267\right)$.

$<$ Figure 3>

\subsection{Sediment sampling and analysis}


Surface sediment samples to a depth of c.5mm were collected at each site, and horizontal flux of wind-blown material was measured using vertical arrays of Fryrear 'Big Spring Number Eight' (BSNE) traps (Fryrear, 1986). Although these are only c.40\% efficient as dust traps, they are widely-used, robust and their efficiency is constant for wind speeds up to $5 \mathrm{~ms}^{-1}$ (Goossens \& Offer, 2000). The BSNE traps were modified to include a rain/snow hood (Shao et al. 1993) and mounted at heights of $0.18 \mathrm{~m}, 0.43 \mathrm{~m}, 0.85 \mathrm{~m}$ and $1.5 \mathrm{~m}$ (numbered trap five to two respectively). Traps were emptied after one week (on: 06-06-07 off: 13-06-07 days 1-7) and again after a further 9 weeks in the field (on: 13-06-07 off: 18-08-07 days $8-65)$.

Sediment characteristics were quantified using two methods - laboratory dry sieving and laser particle sizing - due to the large variation in particle size (silt-sand-gravel) and in quantity of available material, typically $>2 \mathrm{~kg}$ for surface samples but $<5 \mathrm{~g}$ for trapped wind-blown sediments. Surface samples were sieved at $0.5 \phi$ intervals between $45 \mu \mathrm{m}$ and $32 \mathrm{~mm}$. High resolution size analyses were performed on a subset of the surface samples using a Beckman-Coulter LS280 laser-sizer in the range 0.375 to $2000 \mu \mathrm{m}$ with 93 class intervals. The surface sediment samples were initially passed through a $1.4 \mathrm{~mm}$ sieve to exclude coarse fluvial lag deposits and then a c.5g sub-sample was analysed using the laser particle-sizer. Samples collected using the BSNE traps were analysed using the laser particle-sizer only. Due to fundamental differences in measurement techniques, particle size reports from sieving and the laser-sizer may disagree (e.g. Blott \& Pye, 2006, Rodriguez \& Uriarte, 2009); this leads to difficulties combining data obtained from the different sources. In this paper, the sieve data gives an indication of the overall surface sediment characteristics. Laser-sizer data are used to compare the characteristics of the sediment fraction within the surface material that is most likely to be entrained by the wind ( $<1.4 \mathrm{~mm}$ by sieving) with those of the wind-blown sediments.

A few days prior to the start of the monitoring campaign a layer of fine sediment up to $140 \mathrm{~mm}$ deep was deposited on a section of the floodplain following a meltwater flood event. This section of the floodplain is incised 3-4 $\mathrm{m}$ below the level of the five monitoring sites and located $280 \mathrm{~m}$ up valley (towards the ice sheet) from site one. Although there was evidence that some of this flood deposit had already been 
deflated, the bank side sediments were actively deflating during the first week of the experiment (Figure 2d). Three samples of this flood deposit were analysed using the laser-sizer; one on the channel margin (WR003) and two on the fluvial terrace in different positions such that WR001 must have been deposited after WR002.

\section{Results}

During days 1-7, wind speed at the reference station (site three) was, on average, $3.68 \mathrm{~ms}^{-1}$ at $2.4 \mathrm{~m}$ and $2.54 \mathrm{~ms}^{-1}$ at $0.18 \mathrm{~m}$ above the surface, but varied considerably during the experiment (Figure 4). Although tests indicated that it was functioning properly, the Sensit deployed at the reference station did not record any impacts in days 1-7 which meant it was not possible to determine the threshold for aeolian sand transport at the sites using techniques such as the time fraction equivalence method (Stout \& Zobeck, 1996). Dijkmans and Törnqvist (1991) observed that winds exceeding $6 \mathrm{~ms}^{-1}$ were required to entrain silts in this valley and wind velocities had to exceed $7 \mathrm{~ms}^{-1}$ to entrain material in the range $210-300$ $\mu \mathrm{m}$. The mode of the fine fraction of the surface sediments at all the sites used for this study lies in the range 350-650 $\mu \mathrm{m}$. Using Bagnold's (1941) equation for calculating critical shear velocity and the Prandtl-von Karman equation to determine wind speed at a height above the surface, it can be estimated that grains with a diameter of $350 \mu \mathrm{m}$ would be entrained at wind speeds ranging from 4.4-6.0 $\mathrm{ms}^{-1}$ measured at $2.4 \mathrm{~m}$ above the surface, and grains with a diameter of $650 \mu \mathrm{m}$ would require wind speeds in the range 6-8.2 $\mathrm{ms}^{-1}$ (range attributable to variations in surface roughness $\left(z_{0}\right)$ amongst sites). During days $1-7$ approximately $24 \%$ of wind velocities measured at $2.4 \mathrm{~m}$ were in the range $4.4-6 \mathrm{~ms}^{-1}$ and $13 \%$ exceeded $6 \mathrm{~ms}^{-}$ 1.

Near-surface temperature in days 1-7 at the reference station varied from 4.3$23.7^{\circ} \mathrm{C}$ (mean $13.4^{\circ} \mathrm{C}$ ) with clear diurnal variation (Figure 4). Soil moisture was c. $7 \%$ for the first three days and increased to $10.6 \%$ in response to $10 \mathrm{~mm}$ rainfall (measured at Kangerlussuaq) overnight on the 8/9 June followed by a gradual decrease over the remaining largely dry days. Wind direction recorded at the reference station clearly shows the dominance of ice-sheet driven katabatic winds, the resultant direction is $254^{\circ}$ but the distribution is broad reflecting winds channelled from both the Russell and Leverett glaciers (Figure 5). 
For days 8-65 conditions were only recorded at the reference station (site three). Unfortunately a fault with the data logger meant that only data from days 28-65 could be retrieved. Mean wind speed at $2.4 \mathrm{~m}$ was $2.54 \mathrm{~ms}^{-1}$ and at $0.18 \mathrm{~m}$ it was $1.75 \mathrm{~ms}^{-1}$ and only exceeded $4.4 \mathrm{~ms}^{-1}$ and $6 \mathrm{~ms}^{-1}$ for $11 \%$ and $6 \%$ of the time respectively (Figure 6). Total rainfall for this period was $103 \mathrm{~mm}$ of which $83 \mathrm{~mm}$ fell in the last two weeks of July.

$<$ Figure 4>

$<$ Figure 5>

$<$ Figure 6>

Particle-size distributions for the surface sediments at the five sites are shown in Figure 7. The fine fractions, characterised using the laser sizer are shown in the left hand graphs, the coarser fractions (right hand graphs) were characterised by dry sieving. The two distributions are not plotted together as the techniques measure different attributes of the particles, however where the size fractions overlap there are clear similarities in curve-shape and modes. At site one, closest to the ice-margin, sediments are bimodal - with a coarse pebble mode at $>8000 \mu \mathrm{m}$ and a very fine to fine sand mode at $90-180 \mu \mathrm{m}$. The sand mode is also clearly present at the other floodplain sites two and three. Site three is bimodal, similar to site one however the finer mode is more clearly defined. The two dunefield sites furthest from the ice sheet - four and five - have surface sediments typical of sandy aeolian deposits being well-sorted and with a single mode. For sites three to five, the proportion of surface sediment identified as being $<63 \mu \mathrm{m}$ in diameter is similar regardless of which particle-sizing method is used and is $<5 \%$. For site one, lasersizing suggests over $12 \%$ of the surface sediments are silt-sized or smaller compared with $5.6 \%$ by sieving whereas for site two laser sizing suggests $<1.5 \%$ of fine particles compared with $>5 \%$ by sieving. For particles less than $1.4 \mathrm{~mm}$ diameter, the finer sediments are better sorted, coarser skewed and more platykurtic (Figure 8), however there is no significant down valley change in fine sediment size and sorting for this fraction.

$<$ Figure 7>

$<$ Figure 8> 
Fractional speed-up ratios are shown in Figure 9 for three heights and the two dominant wind directions. Figure 9a shows relative wind speeds down valley for winds coming from $40-50^{\circ}$ (recorded at site three); data from all anemometers indicate highest wind speeds nearest the ice sheet (site one; $x=0$ ) with an overall decrease down valley. The anemometers at $2.4 \mathrm{~m}$ above the surface indicate a slight reduction in wind velocity between site one and site two $(\delta s=+0.28$ to +0.16$)$ whilst the lower anemometers indicate little change. Between site two - just over 2 $\mathrm{km}$ from site one and $7 \mathrm{~km}$ from the ice margin on the same bearing - and site four wind velocities at all heights notably reduce $(\delta s=+0.16 /+0.21$ to $-0.15 /-0.29)$ with very little change in topography (13 $\mathrm{m}$ fall over $1.64 \mathrm{~km}$ ). Wind speeds at all heights increase between sites four and five but still remain lower than those recorded at sites one to three. For winds with a direction of $100-110^{\circ}$ (at site three) there is a more rapid reduction in wind speed from site one to site two and at $2.4 \mathrm{~m}$ and $0.43 \mathrm{~m}$ this reduction continues to site three before wind speeds increase to sites four and five. For near surface winds $(0.18 \mathrm{~m})$ the lowest wind speeds are recorded at site two before velocities increase at sites three to five. The mean wind speed recorded at the reference station varies little for the two directions; for $40-50^{\circ}$ winds mean wind speed was $4.75 \mathrm{~ms}^{-1}, 4.21 \mathrm{~ms}^{-1}$ and $3.35 \mathrm{~ms}^{-1}$ at $2.4 \mathrm{~m}, 0.43 \mathrm{~m}$ and $0.18 \mathrm{~m}$ respectively whilst for $100-110^{\circ}$ winds mean wind speed was $4.38 \mathrm{~ms}^{-1}$, $4.15 \mathrm{~ms}^{-1}$ and $3.28 \mathrm{~ms}^{-1}$ at $2.4 \mathrm{~m}, 0.43 \mathrm{~m}$ and $0.18 \mathrm{~m}$.

$<$ Figure 9>

Wind-transported sediments were trapped in all the BSNE samplers at all sites (Figure 10; Table 2). For both sampling periods, the greatest quantity of material was trapped at the sites on the floodplain; site two (42.73 $\mathrm{g}$ after 7 days; $55.51 \mathrm{~g}$ over days 8-65), the next most active site was site three (6.41 $\mathrm{g}$ after 7 days; 25.65 $\mathrm{g}$ days 8-65) followed by site one (5.35 $\mathrm{g}$ after 7 days; $3.58 \mathrm{~g}$ days $8-65)$. For the

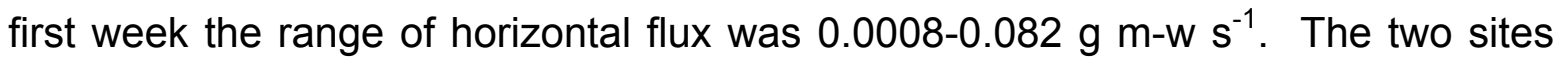
within the dunefield, sites four and five, trapped the least wind-blown material. With the exception of site four (after 7 days) most sediment was trapped closest to the surface in trap number five. The relationship between height (within the limits of the data $z=0.18$ and $1.5 \mathrm{~m}$ ) and mass of sediment can be described as 


$$
m=\alpha z^{-\beta}
$$

where $m$ represents mass of sediment collected through a $10 \mathrm{~cm}^{2}$ orifice (in $\mathrm{g} \mathrm{cm}^{-2}$ ), $z$ is sample height, and $\alpha$ and $\beta$ are regression coefficients (Leys \& McTainsh, 1996). The exponent $\beta$ describes the decrease in the mass of sediment with height and varies from site to site and between the two measurement periods. For both periods $\beta$ decreases down valley from sites one to three before increasing at site four. The coefficient $\alpha$ characterises the density of suspended sediment and for the first measurement period it decreases with distance down valley; for the second measurement period values of $\alpha$ are consistently very low (Table 2).

$<$ Table 2>

The particle-size characteristics of the wind-blown sediments are summarised in Figure 11. Notably all the trapped sediments are multimodal and most have visible modes in the clay $(<4 \mu \mathrm{m})$, very fine silt $(3.9-7.8 \mu \mathrm{m})$ and coarse silt $(31-63 \mu \mathrm{m})$ categories. With the exception of site three, the sediments in the lowest traps are the coarsest but there is no systematic variation in grain size above this and in some instances, the largest mean particle size is found in higher traps. For example, site three after 7 days (lowest trap mean size $9.92 \mu \mathrm{m}$, trap four mean size $25.19 \mu \mathrm{m}$ ) and site two after 65 days (lowest trap mean size $6.59 \mu \mathrm{m}$, trap four mean size $23.13 \mu \mathrm{m}$ ). The channel margin flood deposit (WR003) is bimodal with peaks at $\approx 340 \mu \mathrm{m}$ and $\approx 50 \mu \mathrm{m}$ (Figure 11). The coarse peak is not present in the samples from the terraces (WR001 and WR002); the main peak is c.75 $\mu \mathrm{m}$ for WR002 and c.50 $\mu \mathrm{m}$ for WR001 with all samples also containing material $<4 \mu \mathrm{m}$ diameter.

$<$ Figure 11>

\section{Discussion}

Surface sediments in Sandflugtdalen vary considerably down valley from coarse gravelly-sands at site one to very well-sorted sands at sites four and five. Sites one, two and three are all located on the main floodplain in the valley which is very 
dynamic. During the first week of the experiment the river channel migrated across the floodplain switching overnight from a course to the south of site two to one running north of site two. Although the fluvioglacial gravels are poorly sorted they are well-packed and form a relatively flat surface and sites one and three had the lowest surface roughness $\left(z_{0}\right)$ values at $0.0008 \mathrm{~m}$ and $0.0004 \mathrm{~m}$ respectively. Despite being geomorphologically very different, site two (floodplain) and site four (dunefield) had the same $z_{0}$ value of $0.004 \mathrm{~m}$ possibly due to the presence of large aeolian ripples in each case. The surface characteristics are similar to those reported for other proglacial and paraglacial environments, such as the sandygravels $\left(z_{0}=0.0009-0.0028 \mathrm{~m}\right)$ and sand-fields $\left(z_{0}=0.007 \mathrm{~m}\right)$ in Iceland (Arnalds et al. 2001) and mixed sand and gravel and sand- or silt-dominated deposits of South Island, New Zealand (McGowan \& Sturman, 1997).

There is relatively fine material $(<1.4 \mathrm{~mm}$ diameter) present in the surface sediments at all sites but this is typically much coarser than the trapped wind-blown sediments. The grain sizes of wind-blown material are small with the mean sediment size in all traps for both time periods less than $50 \mu \mathrm{m}$. McGowan \& Sturman (1997) determined a semi-logarithmic relationship, and Nickling (1983) found a linear relationship between grain size and trap height but for this experiment a systematic decrease in sediment size with height was only recorded at site one (days 1-7 and 8-65) and site three (days 8-65). For other cases, the maximum grain size was variously trapped at $0.85 \mathrm{~m}$ (sites two and five; days 8-65) and $1.5 \mathrm{~m}$ (site three, days 1-7). This is uncommon but by no means unique; several studies have noted that the sediment load does not always increase systematically with height above the surface, and that, especially with very small samples such as were obtained here, a low number of larger grains can be accumulated in higher traps during turbulent airflow and affect the mean grain size (e.g. Butler et al. 2005; Dong et al. 2010, Fratini et al. 2009).

Although the Sensit impact sensor was functioning correctly, no impacts were recorded, yet aeolian sediment transport was occurring in the valley as evidenced by the BSNE trap data. The lack of impacts recorded is likely due to the particle size characteristics of the sediments in transport. In $90 \%$ of the BSNE samples (over both time periods) less than $0.25 \%$ of the particles trapped were $>150 \mu \mathrm{m}$ in diameter. For the Sensit H11B to record an impact, a particle must have a 
momentum of $5 \times 10^{-8} \mathrm{~N}$ s and whilst particles of $200 \mu \mathrm{m}$ diameter can attain this at wind speeds of $4.5 \mathrm{~ms}^{-1}$, particles of $150 \mu \mathrm{m}$ and $100 \mu \mathrm{m}$ require wind speeds of 10.68 ms-1 and $36.04 \mathrm{~ms}^{-1}$ respectively (Stout and Zobeck, 1996; Table 3). The maximum wind speeds recorded in this study were $10.13 \mathrm{~ms}^{-1}$ at $2.4 \mathrm{~m}$ and 7.13 $\mathrm{ms}^{-1}$ at $0.18 \mathrm{~m}$ above the surface (based on 10 minute averages) which suggests that any impacts of fine particles in transport would not have been recorded. Such fine particles would also be likely to travel by suspension or modified saltation (Nalpanis, 1985) and hence once entrained would not impact the ground as frequently as coarser saltating particles.

$<$ Table 3>

Comparison of the trapped wind-blown sediments with the recent flood deposit, both of which are dominated by coarse silts, suggests that the latter was the main source of aeolian material. At the channel margin the flood deposit contained medium sands ( $38 \%$ by volume; mode c. $340 \mu \mathrm{m}$ ) and coarse silts ( $15 \%$ by volume; c.50 $\mu \mathrm{m}$ ) but there was an upward fining of the flood deposit and the surface sediments contained predominantly coarse silt (47\%; mode c.c.50 $\mu \mathrm{m})$ and less sand-sized material (28\%). In addition, the lack of impacts recorded by the Sensit at the reference station suggests that trapped material was not derived from the surface sediments immediately around the BSNE sampler, but was transported to the site from the flood deposit described above - whilst winds were strong enough to transport silt-sized material they were less able to entrain and transport local, coarser sand-sized particles. Although site one was closest to the recent flood deposits, very little wind-blown sediment was trapped here compared with sites two and three and less was trapped at three than at site two. A possible explanation is that although the coarser and more poorly-sorted sediments at sites one and three provide a relatively flat, smooth surface with low surface roughness, it is possible for particles travelling by modified saltation or in suspension to be trapped between sediments when do they make contact with the surface and to be deposited. The nature of the surface can also affect sediment transport because saltation efficiency and trajectories are typically higher over coarser surfaces than over sandy surfaces. These two factors combined may explain why there is little variation in sediment load with height at site one. 


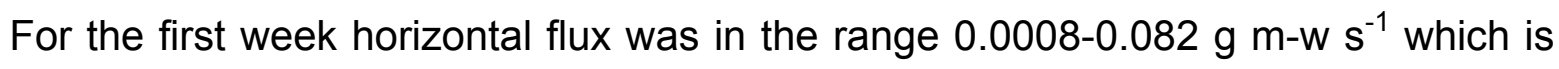
similar to that recorded by McTainsh et al. (1999) for a semi-arid area and Church (1972) who reported transport of $1600 \mathrm{~g} \mathrm{~m}-\mathrm{w}$ month $^{-1}$ on Baffin Island which equates to an average of approximately $0.00062 \mathrm{~g} \mathrm{~m}^{-\mathrm{w} \mathrm{s}^{-1}}$. These values are considerably less than those measured by Nickling (1978) on a proglacial floodplain in Canada, however, Nickling (1978) only measured flux when events were occurring so estimates would be expected to be higher than those averaged over all conditions. For the second period of our study (days 8-65) wind velocities were lower and rainfall was higher than the first seven days meaning that transport capacity was reduced during this time. There were also no significant new flood deposits in the valley during days 8-65 and these two factors (lower transport capacity and reduced sediment supply) led to a lower horizontal flux rate of $0.00035-0.011 \mathrm{~g} \mathrm{~m}^{-\mathrm{w} \mathrm{s}^{-1}}$ over this period. Although it is difficult to disentangle the relative importance of transport capacity and sediment supply in this case, Figure 12 shows the site of the flood deposit in early June and again in mid August 2007 by which time the fluvial silts have been deflated and a single-grain depth lag deposit has formed limiting further aeolian entrainment. This suggests that aeolian activity in the valley may be supply-limited and dependent on fresh deposits of suspended sediments from the catchment. Wind velocities were insufficient to directly mobilise sediment from within the floodplain sediments which are very poorly-sorted.

$<$ Figure 12>

The supply and availability of sediments to the aeolian system are determined by fluvioglacial activity. Although major events, such as catastrophic floods (e.g. jökulhlaups) can flush considerable quantities of fine sediments from beneath the ice (e.g. Old et al. 2005), there are also significant sediments loads in lower magnitude meltwater flood events. Glacier and ice sheet systems are complex and the amount of suspended sediment delivered to the floodplain is not necessarily a function of glacier size and activity but also reflects glacier hydrology and the availability of 'preconditioned' sediment (Anderson, 2007, Jansson et al. 2005). Some meltwater flood events have very high sediment discharges whereas others bring little fresh sediment to the floodplain due to sediment exhaustion (Haritashya 
et al. 2006; Swift et al. 2005). This makes it difficult to predict how much sediment could potentially be transferred to the aeolian system to form proglacial dune systems, to contribute to soil formation in the catchment or to be transported beyond the catchment to impact atmospheric and marine systems. Meltwater suspended sediment concentrations are likely to increase during ice retreat due not only to higher rates of glacier activity and greater water input to glaciers but also because the retreating ice will expose more sediments in the proglacial area to fluvial reworking and entrainment (Jansson et al. 2005).

\section{Conclusions}

From this study we can conclude that during the summer melt season there is considerable potential for the deposition of fine, silt-sized sediments on the proglacial floodplain and that these sediments can be deflated by down valley winds. Deflation of the flood deposit is a rapid process, as also observed by Dijkmans and Törnqvist (1991), and consequently dust production from the proglacial floodplain is supply limited. At present, during the summer months in Sandflugtdalen the older outwash deposits are not a source of dust because siltsized material is largely absent from the sediments. There is, however, a sandsized fraction, but this was not mobilised by the wind, most likely due to low wind velocities and the armouring effect of coarser gravel particles with which the sand is mixed. Sand transport is more likely to occur in the winter months when wind speeds are higher.

\section{Acknowledgements}

This study was funded by The Leverhulme Trust. With thanks to Franziska Jieck, John Anderson and Kangerlussuaq International Science Support for help with fieldwork, planning and logistics, and to Mark Szegner for assistance with preparation of the figures. The article was improved thanks to comments from Amy Draut, Alfonsina Tripaldi and an anonymous reviewer. 


\section{References}

Adhikary, S., Yamaguchi, Y., Ogawa, K. 2002. Estimation of snow ablation under a dust layer covering a wide range of albedo. Hyd. Proc. 16(14), 2853-2865.

Aebly, F.A., Fritz, S.C. 2009. Palaeohydrology of Kangerlussuaq (Sondre Stromfjord), Weat Greenland during the last similar to 8000 years. The Holocene, 19, 91-104.

Alho, P. 2003. Land cover characteristics in NE Iceland with special reference to jökulhlaup geomorphology. Geografiska Annaler, 85A, 213-227.

Anderson, S.P. 2007. Biogeochemistry of Glacial Landscape Systems. Annu. Rev. Earth Planet Sci. 35, 375-399.

Arnalds, O., Gisladottir, F.O., Sigurjonsson, H. 2001. Sandy deserts of Iceland: an overview. J. Arid Env., 47, 359-371.

Bagnold, R.A. 1941. The Physical of Blown Sand and Desert Dunes. Methuen, London.

Ballantyne, C.K. 2002. Paraglacial geomorphology. Quat. Sci. Rev. 21, 1935-2017.

Bauer, B.O., Sherman, D.J., Wolcott, J.F. 1992. Sources of uncertainty in shear stress and roughness length estimates derived from velocity profiles. Professional Geography, 44, 4, 453-464.

Blott, S.J., Pye, K. 2006. Particle-size distribution analysis of sand-sized particles by laser diffraction: an experimental investigation of instrument sensitivity and the effects of particle shape. Sedimentology, 53, 671-685.

Bullard, J.E., Anderson, N.J., Scott, D. 2009. Aeolian sediment source response to climate change and ice-retreat: evidence from aeolian silt deposition in a high altitude lake, West Greenland. Eos Trans. American Geophysical Union, 90(52) Fall Meeting Supplementary, Abstract PP415-1535.

Bullard, J.E., Livingstone, I. 2002. Interactions between aeolian and fluvial systems in dryland environments. Area, 34, 8-16.

Butler, H.J., McTainsh, G.H., Hogarth, W.L., Leys, J.F. 2005. Kinky profiles: effects of soil surface heating upon vertical dust concentration profiles in the Channel Country of western Queensland, Australia. J. Geophys. Res. 110, F04025, doi:10.1029/2004JF000272.

Carstensen, L.S., Jørgensen, B.V. 2009. Weather and Climate Data from Greenland 19582008. DMI Technical Report 09-11. Copenhagen. 
Church, M. 1972. Baffin Island Sandurs: a study of Arctic fluvial processes. Geological Survey of Canada Bulletin 216. Department of Energy, Mines and Resources, Canada.

Derbyshire, E.D., Owen, L.A. 1996. Glacioaeolian processes, sediments and landforms. In Menzies, J. (ed) Past Glacial environments, sediments, forms techniques. Butterworth-Heinemann Ltd. Oxford. 213-237.

Dijkmans, J.W.A., Törnqvist, T.E. 1991. Modern periglacial eolian deposits and landforms in the Søndre Strømfjord area, West Greenland and their palaeoenvironmental implications. Meddelelser om Grønland, Geosci. , 25, 7-19.

Dong, Z., Man, D., Luo, W., Qian, G., Wang, J., zhao, M., Liu, S., Zhu, G., Zhu, S. 2010. Horizontal aeolian sediment flux in the MInqin area, a major source of Chinese dust storms. Geomorphology, 116, 58-66.

Fratini, G., Santini, M., Ciccioli, P., Valentini, R. 2009. Evaluation of a wind erosion model in a desert area of northern Asia by eddy covariance. Earth Surf. Proc. Landf. 34, 1743-1757.

Field, J.P., Breshears, D.B., Whicker, J.J. 2009. Toward a more holistic perspective of soil erosion: why aeolian research needs to explicitly consider fluvial processes and interactions. Aeolian Research, 1, 9-17.

Friberg, N., Milner, A.M., Svendsen, L.M., Lindegaard, C., Larsen, S.E. 2001. Macroinvertebrate stream communities along regional and physico-chemical gradients in Western Greenland. Freshwater Biology, 46, 1753-1764.

Fryrear, D.W. 1986. A field dust sampler. J. Soil Water Cons. . 41, 117-120.

Gisladottir, F.O., Arnalds, O, Gisladottir, G. 2005. The effect of landscape and retreating glaciers on wind erosion in south Iceland. Land Degrad. Dev., 16, 177-187.

Glasser, N.F., Hambrey, M.J. 2002. Sedimentary facies and landform genesis at a temperate outlet glacier: Soler Glacier, North Patagonian Icefield. Sedimentology, 49, 43-64.

Goossens, D., Offer, Z.Y. 2000. Wind tunnel and field calibration of six aeolian dust samplers. Atmos. Env., 34, 1043-1057.

Haritashya, U.K., Singh, P., Kumar, N., Gupta, R.P. 2006. Suspended sediment from the Gangotri Glacier: quantification, variability and associations with discharge and air temperature. J. Hyd. 321, 116-130.

Hobbs, W.H. 1942. Wind: the dominant transportation agent within extramarginal zones to continental glaciers. J. Geol. , 39, 381-385. 
Hodgkins, R., Cooper, R., Wadham, J., Tranter, M. 2003. Suspended sediment fluxes in a high-Arctic glacierised catchment: implications for fluvial sediment storage. Sed. Geol. 162, 105-117.

Jackson, P.S., Hunt, J.C.R. 1975. Turbulent wind flow over a low hill. Quat. J. Royal Met. Soc. $101,929-955$.

Jansson, P., Rosqvist, G., Schneider, T. 2005. Glacier fluctuations, suspended sediment flux and glacio-lacustrine sediments. Geografiska Annaler, 87A, 37-50.

Kurosaki, Y., Mikami, M. 2004. Effect of snow cover on threshold wind velocity of dust outbreak. Geophys. Res. Let., 31, L03106, doi:10.1029/2003GL018632.

Lambert, F., Delmonte, B., Petit, J.R., Bigler, M., Kaufmann, P.R., Hutterli, M.A., Stocker, T.F., Ruth, U., Steffensen, J.P., Maggi, V. 2008. Dust-climate couplings over the past 800,000 years from the EPICA Dome $C$ ice core. Nature, 452, 616-619.

Leys, J.F., McTainsh, G.H. 1996. Sediment fluxes and particle grain-size characteristics of wind-eroded sediments in southeastern Australia. Earth Surf. Proc. Landf. 21, 661-671.

McGowan, H.A, Sturman, A.P. 1997. Characteristics of aeolian grain transport over a fluvio-glacial lacustrine braid delta, Lake Tekapo, New Zealand. Earth Surf. Proc. Landf., 22, 773-784.

McKenna Neuman, C., Gilbert, R. 1986. Aeolian processes and landforms in glaciofluvial environments of southeastern Baffin Island, NWT Canada, In Nickling, W.G. (ed) Aeolian Geomorphology. Allen \& Unwin, Boston, 213-235.

McKenna Neuman, C. 2004. Effects of temperature and humidity upon the transport of sedimentary particles by wind. Sedimentology, 51(1), 1-17.

McTainsh, G.H., Leys, J.F., Nickling, W.G. 1999. Wind erodibility of arid lands in the Channel country of western Queensland, Australia. Z. für Geomorph., Suppbd 116, 113-130.

Marx, S.K., McGowan, H.A. 2005. Dust transportation and deposition in a superhumid environment, West Coast, South Island, New Zealand. Catena, 59, 147-171.

Mernild, S.H., Hasholt, B., Kane, D.L., Tidwell, A.C. 2008. Jökulhlaup observed at Greenland ice sheet. Eos Trans. American Geophysical Union, 89(35), 321-322.

Mountney, N.P., Russell, A.J. 2009. Aeolian dune-field development in a water-table controlled system: Skeidararsandur, Southern Iceland. Sedimentology, 56, 21072131. 
Muhs, D.R., McGeehin, J.P., Beann, J., Fisher, E. 2004. Holocene loess deposition and soil formation as competing processes, Matanuska Valley, southern Alaska. Quat. Res., 61, 265-276.

Nalpanis, P. 1985. Saltating and suspended particles over flat and sloping surfaces. II. Experiments and numerical simulations. In Barndorff-Nielson, O.E., Møller, J.T., Romer-Rasmussen, K., Willetts, B.B. (eds) Proceedings of International Workshop on the physics of Blown Sand, Aarhus, 38-31 May 1985. Department of Theoretical Statistics, University of Aarhus Mem. 8, 1, 37-66.

Nickling, W.G. 1978. Eolian sediment transport during dust storms: Slims River Valley, Yukon Territory. Can. J. Earth Sci., 15, 1069-1084.

Nickling, W.G. 1983. Grain-size characteristics of sediments transported during dust storms. J. Sed. Pet., 53, 1011-1024.

Oerlemans, J., Giesen, R.H., van den Broeke, M.R. 2009. Retreating alpine glaciers: increased melt rates due to accumulation of dust (Vadret da Morteratsch, Switzerland). J. Glac. 55, 729-736.

Old, G.H., Lawler, D.M., Snorrason, A. 2005. Discharge and suspended sediment dynamics during two jökulhlaups in the Skafta River, Iceland. Earth Surf. Proc. Landf. 30, 1441-1460.

Riezobos, P.A., Boulton, G.S., van der Meer, J.J.M., Ruegg, G.H.J., Beets, D.J., Castel, I.I.Y., Hart, J., Quinn, I., Thornton, M., van der Wateren, F.M. 1986. Products and effects of modern aeolian activity on a nineteenth-century glacier-pushed ridge in West Spitsbergen, Svalbard. Arctic and Alpine Res., 18, 389-396.

Rodriguez, J.G., Uriarte, A. 2009. Laser diffraction and dry-sieving grain size analyses undertaken on fine and medium-grained sandy marine sediments: a note. J. Coastal Res. 25, 257-264.

Russell, AJ, Van Tatenhove, FGM, Van de Wal, RSW 1995. Effects of ice-front collapse and flood generation on a proglacial river channel near Kangerlussuaq (Søndre Strømfjord), West Greenland. Hydrol. Proc. 9, 213-26.

Schwan, J.1986. The origin of horizontal alternating bedding in Weichselian aeolian sands in northwestern Europe. Sed. Geol. 49, 73-108.

Selby, M.J., Rains, R.B., Palmer, R.W.P. 1974. Eolian deposits of the ice-free Victoria Valley, Southern Victoria Land and Antarctica. New Zealand J. Geol. Geophys., $17,543-562$. 
Seppälä, M. 2004. Wind as a geomorphic agent in cold climates. Cambridge University Press, Cambridge.

Shao, Y., McTainsh, G.H., Leys, J.F., Raupach, M.R. 1993. Efficiencies of sediment samplers for wind erosion measurement. Australian Journal of Soil Research, 31, 519-532.

Steffensen, J.P. 1985. Microparticles in snow from the Greenland ice sheet. Tellus, 37B, 286-295.

Stout, J. E., Zobeck, T.M. 1996. Establishing the threshold condition for soil movement in wind-eroding fields. Proceedings of the International Conference on Air Pollution from Agricultural Operations. MWPS C-3, Kansas City, 7-9 February 1996, pp. 6571.

Sugden, D.E., Clapperton, C.M., Knight, P.G. 1985. A jökulhlaup near Søndre Strømfjord, West Greenland, and some effects on the ice sheet margin. J. Glac., 31, 366-368.

Sugden, D.E., McCulloch, R.D., Bory, A.J.-M, Hein, A.S. 2009. Influence of Patagonian glaciers on Antarctic dust deposition during the last glacial period. Nature Geoscience, doi:10.1038/NGEO474.

Swift, D.A., Nienow, P.W., Hoey, T.B. 2005. Basal sediment evacuation by subglacial metwater: suspended sediment transport from Haut Glacier d'Arolla, Switzerland. Earth Surf. Proc. Landf. 30, 867-883.

Willemse, N.W., Koster, E.A., Hoogakker, B., van Tatenhove, F.G.M. 2003. A continuous record of Holocene eolian activity in West Greenland. Quat. Res., $59,322-334$.

Zdanowicz, C.M., Zielinski, G.A., Wake, C.P. 1998. Characteristics of modern atmospheric dust deposition in snow on the Penny Ice Cap, Baffin Island, Arctic Canada. Tellus, 50B, 506-520. 


\section{Figures}

Figure 1 Map of the study area indicating main area of aeolian deposits and location of five sampling sites.

Figure 2 (a) West end of fieldsite, looking southwest showing the Watson River to the left, the dunefield within which sites four and five were located in the centre, distance across the centre of the photograph is approximately $1.5 \mathrm{~km}$, (b) dunes accumulating around shrub vegetation on the north side of the valley, (c) aeolian ripples upwind of BSNE samplers at site two, (d) active deflation of recent flood deposits; site one is located on the terrace in the background, terrace height approximately $3 \mathrm{~m}$.

Figure 3 Upper panel: oblique aerial photograph of the main sand sheet in Sandflugtdalen showing location of the five sample sites, the distance from site one to site five is $4.2 \mathrm{~km}$, dominant aeolian transport direction is from right to left. Lower panel: surface sediments at each site, each image shows an area $32 \times 32 \mathrm{~mm}$.

Figure 4 a) Wind velocity at $2.4 \mathrm{~m}$ and $0.18 \mathrm{~m}$ above the surface, b) air temperature and soil moisture variability both measured at the reference station (site three) from 6-12 June 2007.

Figure 5 Weather data for 6 June to 19 August 2007. Wind velocity at (a) $2.4 \mathrm{~m}$ and (b) $0.18 \mathrm{~m}$ above the surface measured at site three, C) air temperature recorded at site three (solid line) and Kangerlussuaq (dotted line; see text for details), d) rainfall measured at Kangerlussuaq.

Figure 6 Directional variability of all winds $>3 \mathrm{~ms}^{-1}$ from 6-12 June 2007 measured at the reference station (site three). 
Figure $7 \quad$ Surface grain size characteristics for sites one to five. Left hand graphs show finer fraction determined using laser sizer for particles $<1.4 \mathrm{~mm}$ (by sieving). Right hand graphs depict sediments dry sieved to $45 \mu \mathrm{m}$. Vertical line indicates $63 \mu \mathrm{m}$ and number in italics indicates the percentage of material finer than this.

Figure 8 Relationship between mean grain size, sorting and kurtosis for surface sediment fraction $<1.4 \mathrm{~mm}$ diameter (by sieving).

Figure 9 Time-averaged wind speeds (fractional speed-up ratios) down valley at three sampling heights for winds approaching at (a) 40$50^{\circ}$ and (b) $100-110^{\circ}$. N.B. wind direction is from left to right.

Figure 10 Sediment load trapped in BSNE samplers for days 1-7 and days 8-65. At each site, trap two is mounted at $1.5 \mathrm{~m}$ above the surface, trap three at $0.85 \mathrm{~m}$, trap four at $0.43 \mathrm{~m}$ and trap five at $0.18 \mathrm{~m}$.

Figure 11 Particle-size distributions for trapped sediments at each site for days 1-7 and 8-65. In each case the distribution for surface sediments $(<1.4 \mathrm{~mm})$ is also plotted for comparison. Panel $\mathrm{K}$ shows the particle-size distribution for fluvial silt deposits. WR003 is a channel margin deposit; WR002 and WR001 are floodplain deposits.

Figure 12 Fluvial sediments $270 \mathrm{~m}$ up valley from site one in a) early June 2007 clearly showing a layer of silts (pale colour) deposited on top of fluvial gravels and b) mid-August when most of the siltsized material has been deflated and a lag deposit has formed limiting further aeolian entrainment. 
Table 1. Site description and data collection schedule. Reference station $(R)$ was permanently located at site three; mobile station $(\mathrm{M})$ was deployed at site three for 4 hours to enable cross-calibration of instruments. Surface roughness $\left(\mathrm{z}_{0}\right)$ was estimated graphically using multiple velocity profiles for different wind speeds $>3 \mathrm{~m}^{-1}$ (Bauer et al. 1992).

\begin{tabular}{|c|c|c|c|c|c|c|c|c|}
\hline \multirow[t]{3}{*}{ Site } & \multirow[t]{3}{*}{ Location } & \multirow[t]{3}{*}{ Description } & \multicolumn{5}{|c|}{ Collection of wind speed } & \multirow{3}{*}{$\begin{array}{l}\text { Surface } \\
\quad \mathrm{z}_{0} \\
\mathrm{~m}\end{array}$} \\
\hline & & & \multicolumn{2}{|c|}{ On } & \multicolumn{2}{|c|}{ Off } & \multirow[t]{2}{*}{ Hours } & \\
\hline & & & Date & Time & Date & Time & & \\
\hline 1 & $\begin{array}{l}\text { N6703'59.4" } \\
\text { W50²0'17.5" }\end{array}$ & $\begin{array}{l}\text { Gravel bar, flat with few dry channels }(<0.7 \mathrm{~m} \text { deep). } \\
\text { Gravel clasts partially embedded in sand. No higher } \\
\text { vegetation. }\end{array}$ & $10-06-07$ & 18.12 & $13-06-07$ & 09.12 & 63 & 0.0008 \\
\hline 2 & $\begin{array}{l}\text { N6703'36.7" } \\
\text { W50²3'17.7" }\end{array}$ & $\begin{array}{l}\text { Floodplain, coarse-fine sands and gravel. Two scales } \\
\text { of aeolian ripple - coarse sand ripple wavelength } 1.5 \\
\mathrm{~m} \text {, ht } 20 \mathrm{~cm} \text {; fine sand ripple wavelength }<20 \mathrm{~cm} \text {, ht } 1- \\
2 \mathrm{~cm} .<2 \% \text { vegetation comprising isolated grass } \\
\text { stands } \approx 10 \mathrm{~cm} \text { tall. }\end{array}$ & 09-06-07 & 19.06 & $10-06-07$ & 17.27 & 22 & 0.004 \\
\hline 3 & $\begin{array}{l}\text { N6703'28.0" } \\
\text { W50²4'26.5" }\end{array}$ & $\begin{array}{l}\text { Floodplain, two scales of aeolian ripples (as site } 2) \text {. } \\
\text { Surface sediment predominantly coarse-fine sand, but } \\
\text { some gravel patches. Vegetation cover }<5 \% \text { grasses, } \\
\text { numerous small lee dunes ( } 10 \mathrm{~cm} \text { high, } 20-30 \mathrm{~cm} \\
\text { long). }\end{array}$ & $\begin{array}{l}06-06-07 \\
09-06-07 \\
09-06-07 \\
12-06-07\end{array}$ & $\begin{array}{l}13.52 \\
13.02 \\
13: 44 \\
15.35\end{array}$ & $\begin{array}{l}8-06-07 \\
12-06-07 \\
09-06-07 \\
12-06-07\end{array}$ & $\begin{array}{l}22.29 \\
01.08 \\
18: 04 \\
23.06\end{array}$ & $\begin{array}{ll}57 & R \\
60 & R \\
4 & M \\
7 & R\end{array}$ & 0.0004 \\
\hline 4 & $\begin{array}{l}\text { N6703'19.3" } \\
\text { W50²5'25.6" }\end{array}$ & $\begin{array}{l}\text { Windward slope of dunefield above floodplain. } \\
\text { Aeolian dunes } 1-2.5 \mathrm{~m} \text { tall (none within } 20 \mathrm{~m} \text { of } \\
\text { instruments). }<10 \% \text { vegetation cover comprising low } \\
\text { shrubs and grasses. Aeolian ripples, patches of fine } \\
\text { sands and silt deposits. }\end{array}$ & $08-06-07$ & 11.40 & 09-06-07 & 13.03 & 25 & 0.004 \\
\hline 5 & $\begin{array}{l}\text { N6703'23.0" } \\
\text { W50²5'44.7" }\end{array}$ & $\begin{array}{l}\text { Upper section of dunefield between two moraine } \\
\text { ridges. Mainly sand with finer sediments in shallow } \\
\text { rills; fine sand accumulations around grasses, } \\
\text { vegetation cover }<5 \% \text {. }\end{array}$ & $07-06-07$ & 11.32 & $08-06-07$ & 11.02 & 23 & 0.002 \\
\hline
\end{tabular}


Table 2. Sediment load collected in BSNE samplers for two time periods and regression coefficients summarising density $[\alpha]$ and vertical distribution of suspended sediment [ $\beta]$ (after Leys \& McTainsh, 1996)

\begin{tabular}{|c|c|c|c|c|c|c|c|c|c|}
\hline \multicolumn{6}{|c|}{ Sediment Load (g) } & \multicolumn{4}{|c|}{ Regression Coefficients } \\
\hline & \multirow{2}{*}{$\begin{array}{l}\text { Trap } \\
\text { no. }\end{array}$} & \multirow{2}{*}{$\mathrm{Ht}(\mathrm{m})$} & \multirow{2}{*}{$\begin{array}{l}\text { Days } \\
1-7\end{array}$} & \multirow{2}{*}{$\begin{array}{l}\text { Days } \\
8-65\end{array}$} & \multirow{2}{*}{$\begin{array}{l}\text { Total } \\
\text { Load }\end{array}$} & \multicolumn{2}{|c|}{ Days 1-7 } & \multicolumn{2}{|c|}{ Days 8-65 } \\
\hline & & & & & & $\alpha$ & $\beta$ & $\alpha$ & $\beta$ \\
\hline \multirow{4}{*}{$\frac{\bar{\phi}}{\bar{\omega}}$} & $1-2$ & 1.50 & 1.31 & 0.22 & 1.53 & \multirow[b]{4}{*}{0.120} & \multirow[b]{4}{*}{-0.089} & \multirow[b]{4}{*}{0.003} & \multirow[b]{4}{*}{-1.208} \\
\hline & $1-3$ & 0.85 & 1.37 & 0.27 & 1.64 & & & & \\
\hline & $1-4$ & 0.43 & 1.12 & 0.44 & 1.56 & & & & \\
\hline & $1-5$ & 0.18 & 1.55 & 2.65 & 4.20 & & & & \\
\hline \multirow{4}{*}{$\begin{array}{l}\sim \\
0 \\
\dot{\omega} \\
\dot{\omega}\end{array}$} & $2-2$ & 1.50 & 2.34 & 0.50 & 2.84 & \multirow[b]{4}{*}{0.208} & & \multirow[b]{4}{*}{0.012} & \multirow[b]{4}{*}{-1.842} \\
\hline & $2-3$ & 0.85 & 2.64 & 4.35 & 7.00 & & & & \\
\hline & $2-4$ & 0.43 & 1.56 & 0.96 & 2.52 & & & & \\
\hline & $2-5$ & 0.18 & 36.2 & 49.7 & 85.9 & & -1.227 & & \\
\hline \multirow{4}{*}{$\begin{array}{l}m \\
\stackrel{0}{\infty} \\
\dot{m}\end{array}$} & $3-2$ & 1.50 & 0.14 & 0.21 & 0.36 & \multirow[b]{4}{*}{0.017} & & \multirow[b]{4}{*}{0.004} & \multirow[b]{4}{*}{-2.326} \\
\hline & $3-3$ & 0.85 & 0.18 & 0.36 & 0.54 & & & & \\
\hline & $3-4$ & 0.43 & 0.41 & 1.51 & 1.91 & & & & \\
\hline & $3-5$ & 0.18 & 5.68 & 23.6 & 29.3 & & -1.807 & & \\
\hline \multirow{4}{*}{$\begin{array}{l}\stackrel{+}{0} \\
\stackrel{ \pm}{\omega}\end{array}$} & $4-2$ & 1.50 & 0.17 & 0.32 & 0.49 & \multirow[b]{4}{*}{0.006} & & \multirow[b]{4}{*}{0.004} & \multirow[b]{4}{*}{-0.897} \\
\hline & $4-3$ & 0.85 & 0.01 & 0.44 & 0.44 & & & & \\
\hline & $4-4$ & 0.43 & 0.15 & 0.61 & 0.76 & & & & \\
\hline & $4-5$ & 0.18 & 0.08 & 2.09 & 2.17 & & -0.191 & & \\
\hline \multirow{4}{*}{$\begin{array}{l}0 \\
\stackrel{0}{*} \\
\stackrel{5}{\omega}\end{array}$} & $5-2$ & 1.50 & 0.01 & 0.10 & 0.11 & \multirow[b]{4}{*}{0.004} & & \multirow[b]{4}{*}{0.002} & \multirow[b]{4}{*}{-1.150} \\
\hline & $5-4$ & 0.85 & 0.92 & 0.17 & 1.09 & & & & \\
\hline & $5-3$ & 0.43 & 0.01 & 0.27 & 0.28 & & & & \\
\hline & $5-5$ & 0.18 & 2.35 & 1.16 & 3.50 & & -1.836 & & \\
\hline
\end{tabular}


Table 3: $\quad$ Wind speeds required for particles of different diameters to attain sufficient momentum to be recorded by Sensit H11B (Stout \& Zobeck, 1996) and the percentage of particles of each diameter observed in the surface sediments (Surf.) and trapped sediments (BSNE) at each site.

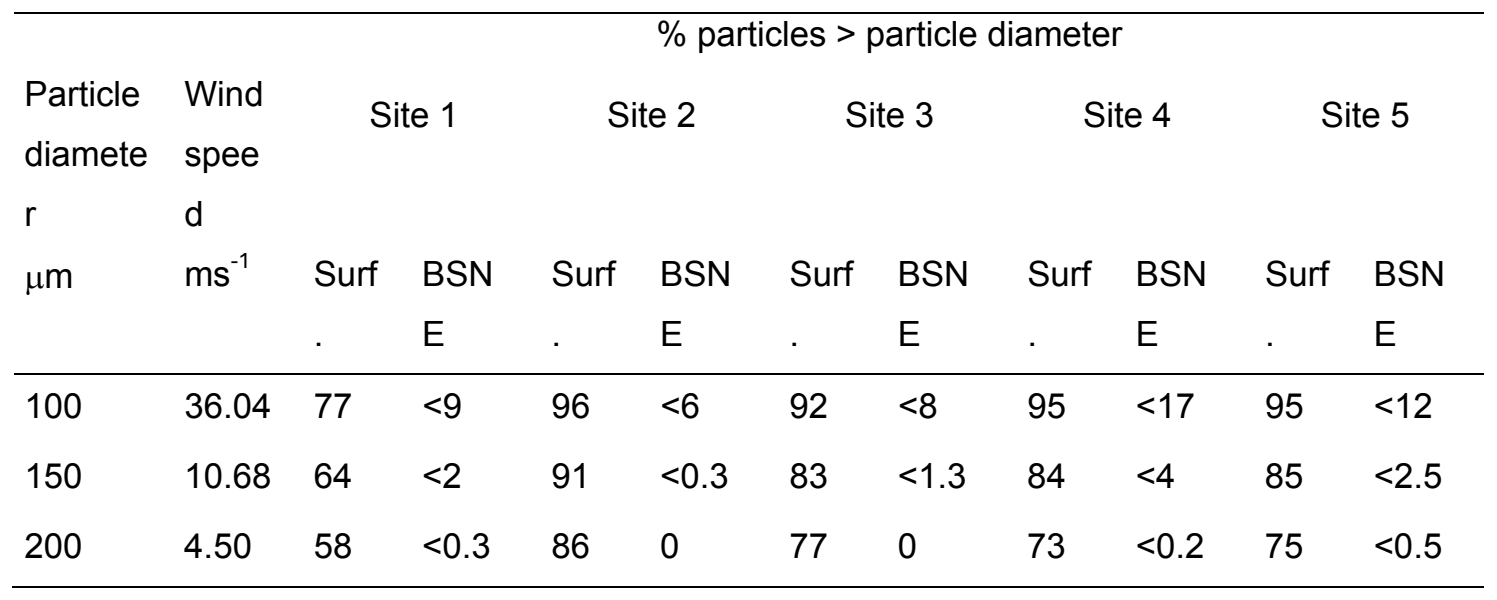


Figure 1 Map of the study area indicating main area of aeolian deposits and location of five sampling sites.

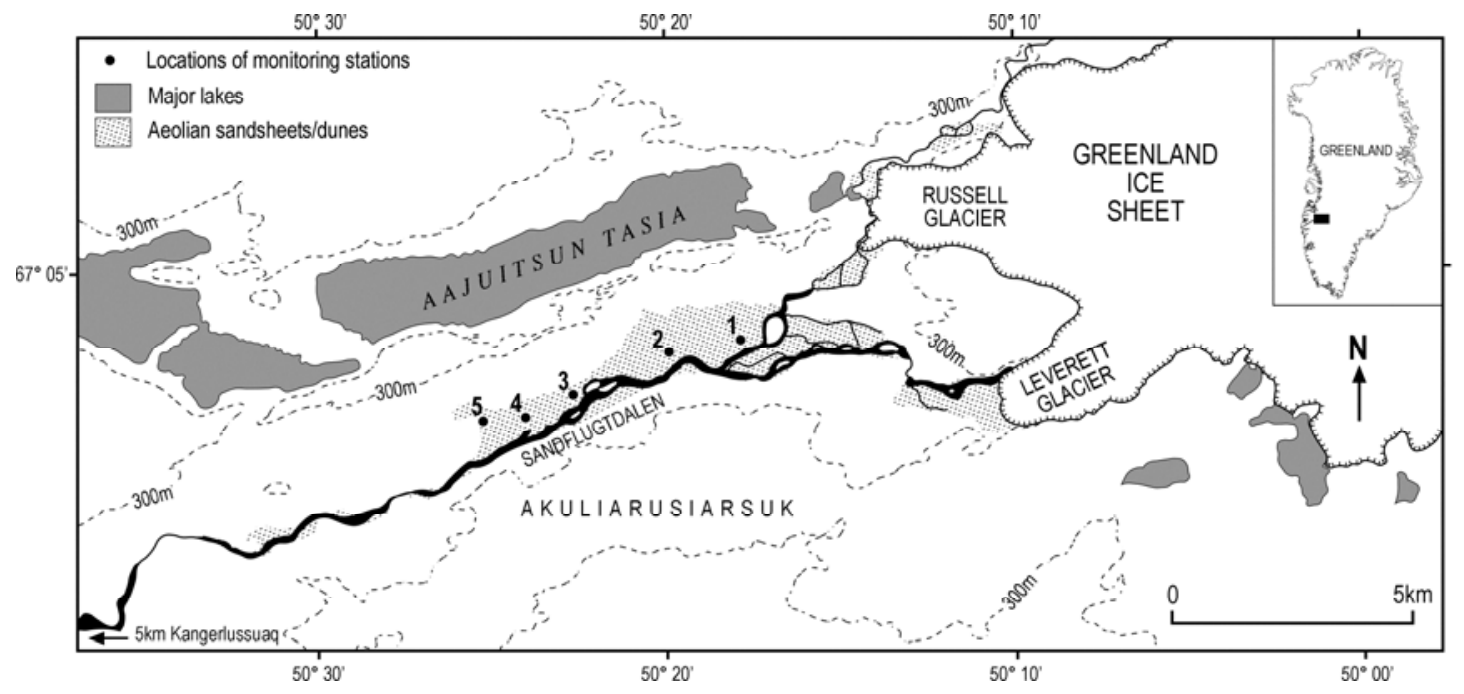


Figure 2 (a) West end of fieldsite, looking southwest showing the Watson River to the left, the dunefield within which sites four and five were located in the centre, distance across the centre of the photograph is approximately $1.5 \mathrm{~km}$, (b) dunes accumulating around shrub vegetation on the north side of the valley, (c) aeolian ripples upwind of BSNE samplers at site two, (d) active deflation of recent flood deposits; site one is located on the terrace in the background, terrace height approximately $3 \mathrm{~m}$.

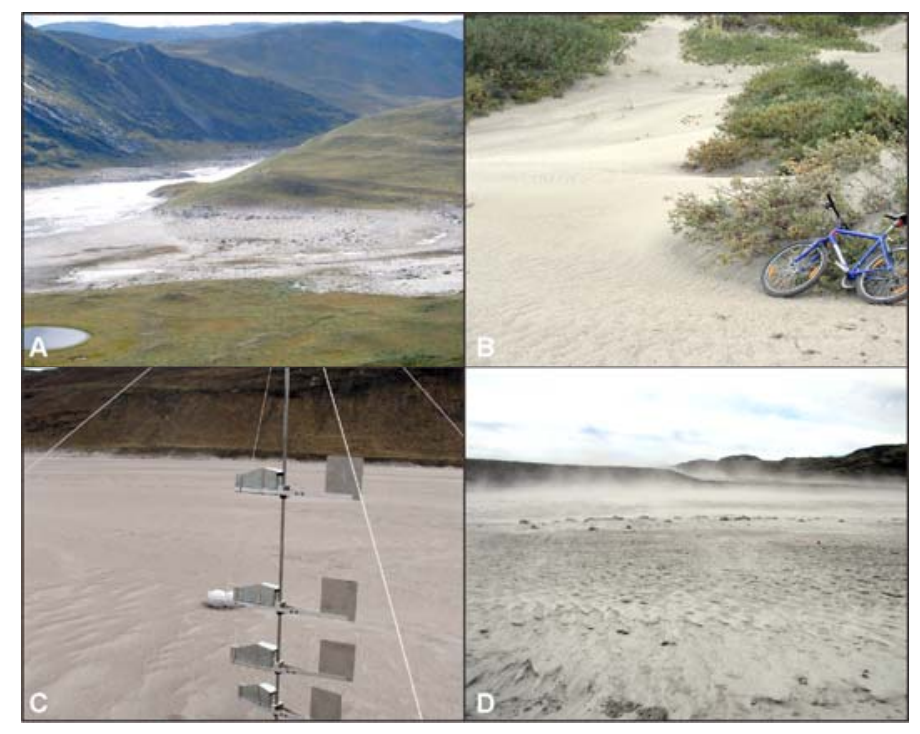


Figure 3 Upper panel: oblique aerial photograph of the main sand sheet in Sandflugtdalen showing location of the five sample sites, the distance from site one to site five is $4.2 \mathrm{~km}$, dominant aeolian transport direction is from right to left. Lower panel: surface sediments at each site, each image shows an area $32 \times 32 \mathrm{~mm}$.

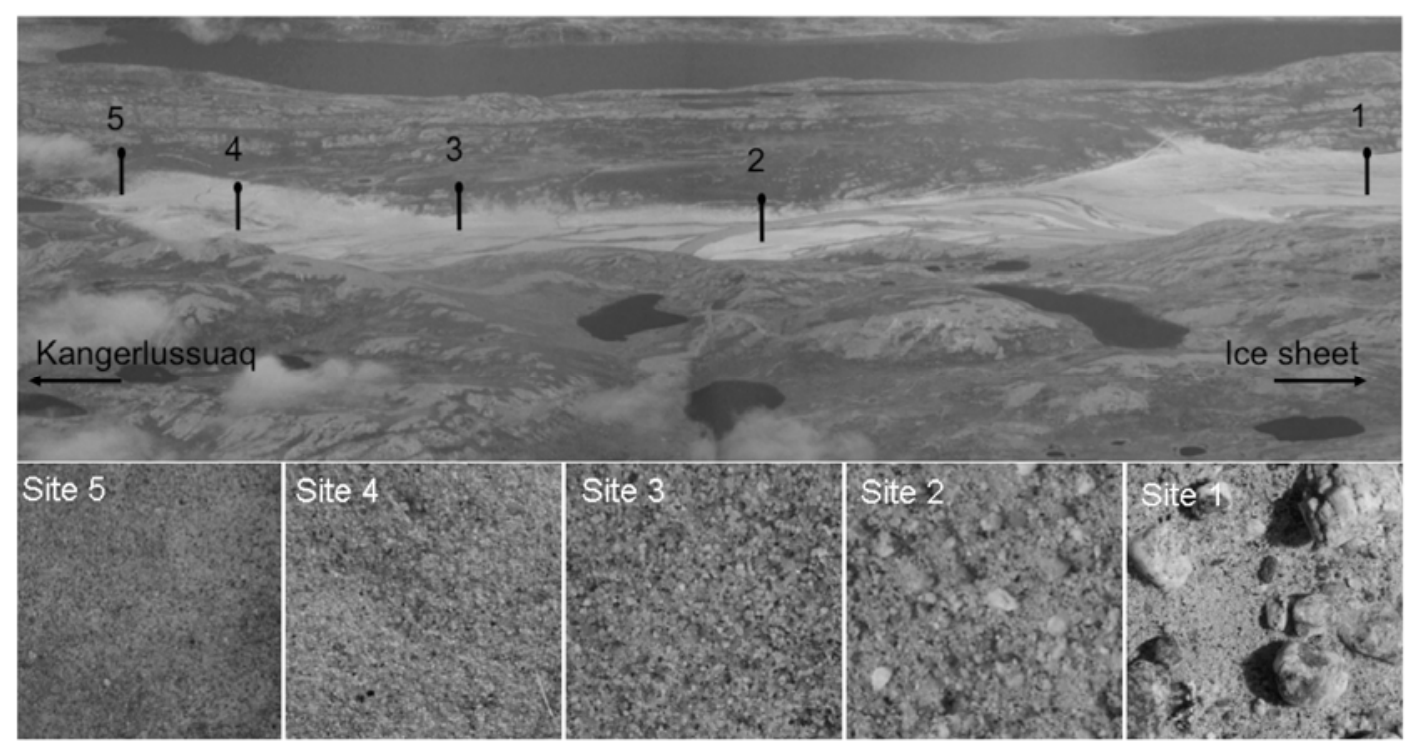


Figure 4

a) Wind velocity at $2.4 \mathrm{~m}$ and $0.18 \mathrm{~m}$ above the surface, b) air temperature and soil moisture variability both measured at the reference station (site three) from 6-12 June 2007.
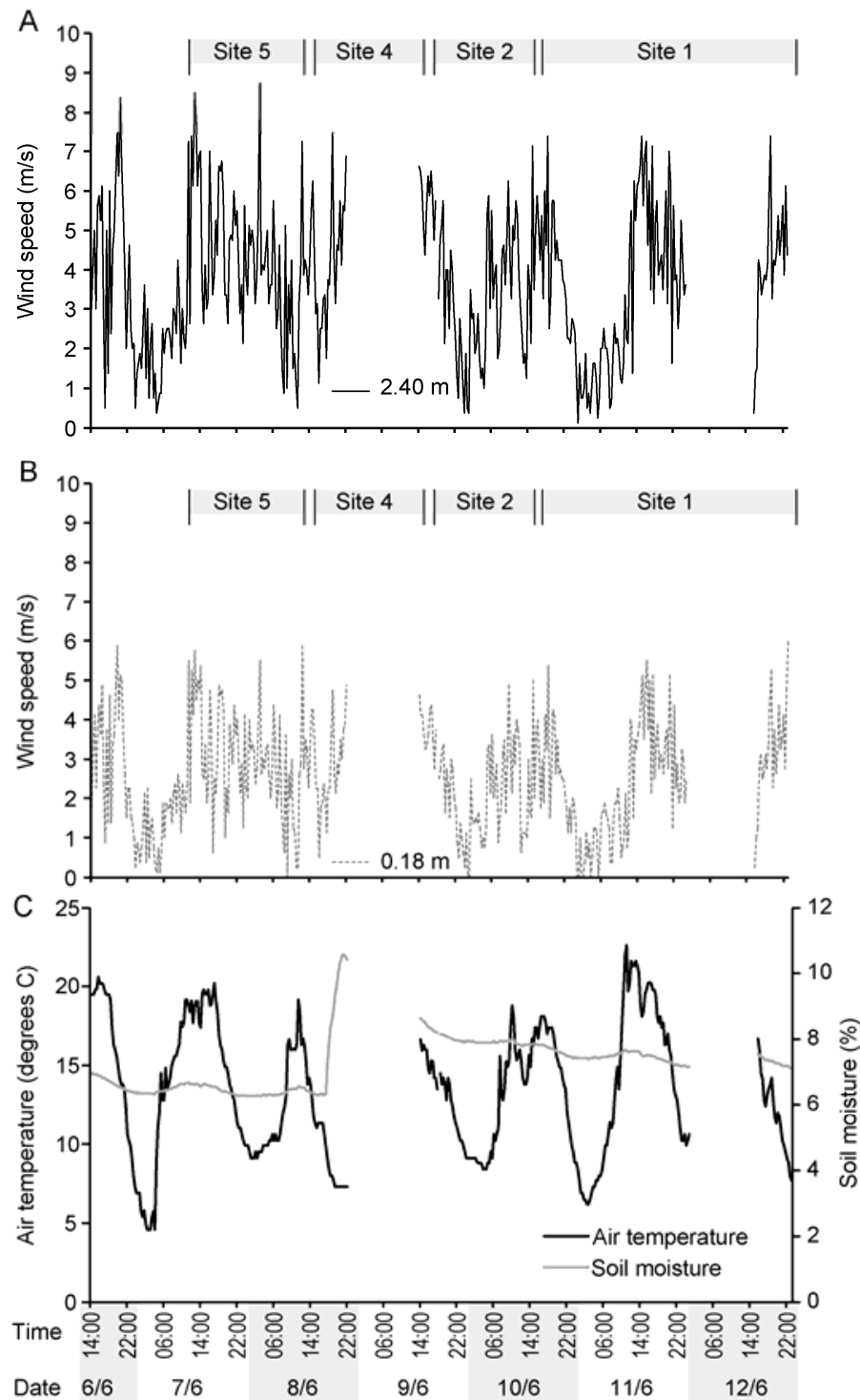
Figure 5 Weather data for 6 June to 19 August 2007. Wind velocity at (a) $2.4 \mathrm{~m}$ and (b) $0.18 \mathrm{~m}$ above the surface measured at site three, c) air temperature recorded at site three (solid line) and Kangerlussuaq (dotted line; see text for details), d) rainfall measured at Kangerlussuaq.
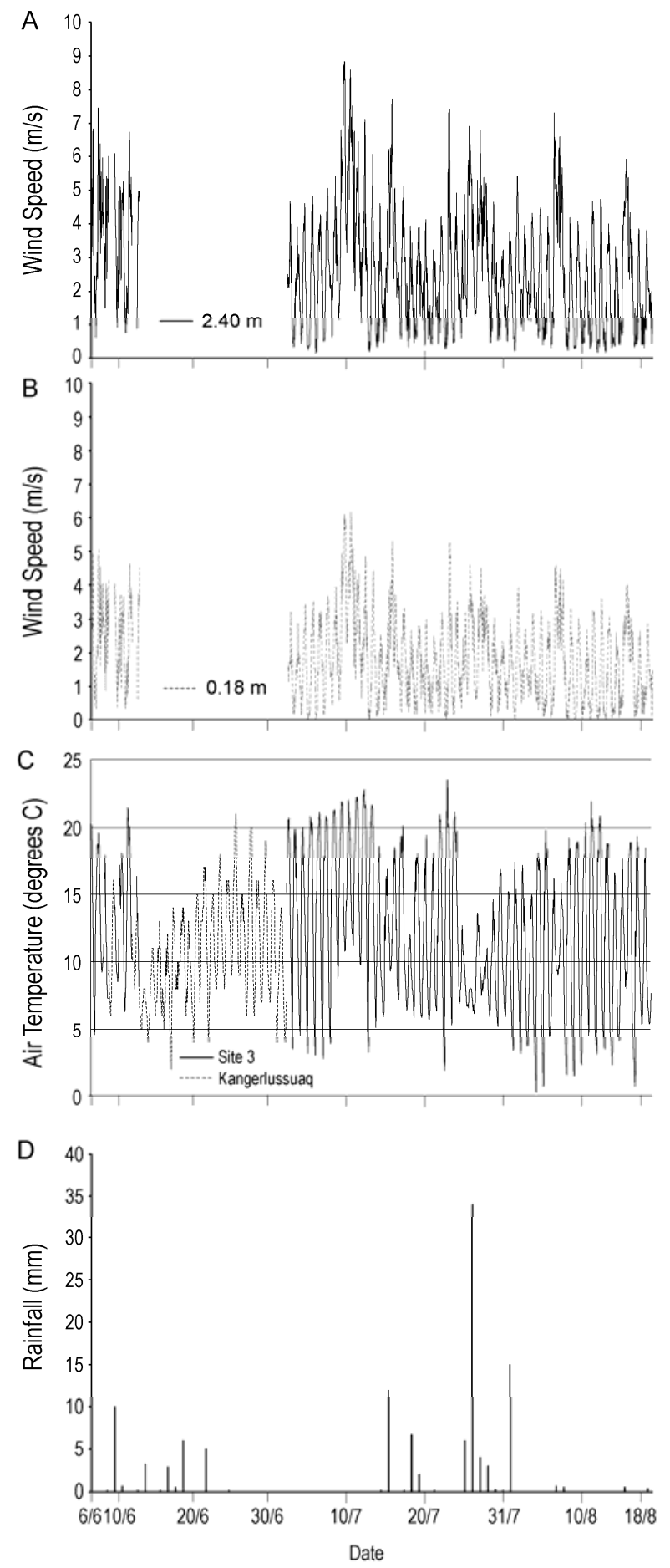
Figure 6 Directional variability of all winds $>3 \mathrm{~ms}^{-1}$ from 6-12 June 2007 measured at the reference station (site three).

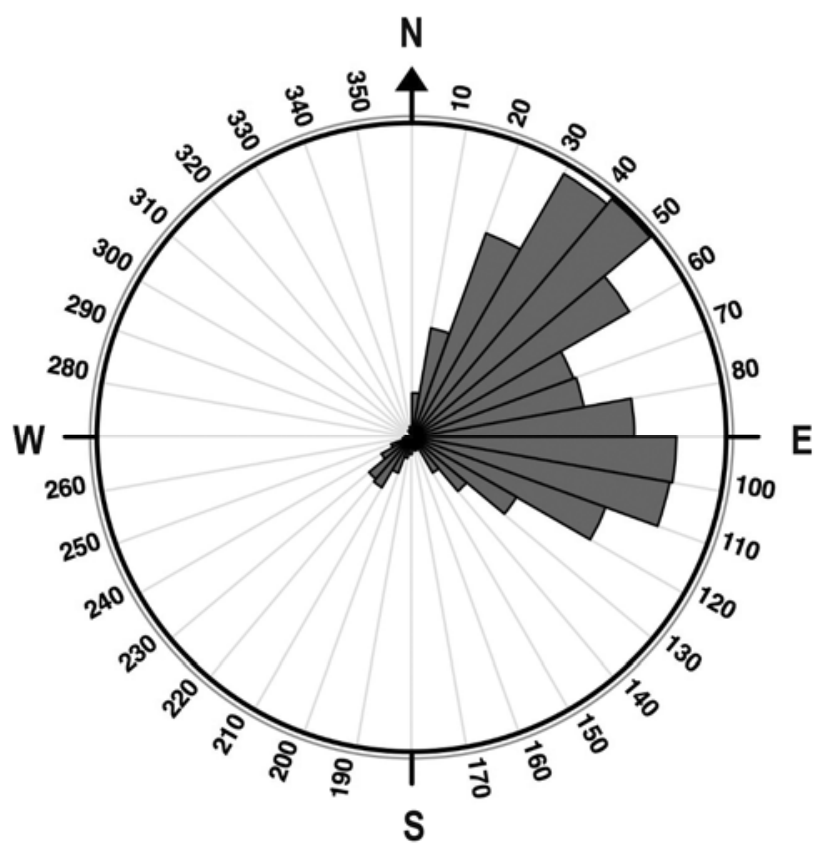


Figure $7 \quad$ Surface grain size characteristics for sites one to five. Left hand graphs show finer fraction determined using laser sizer for particles $<1.4 \mathrm{~mm}$ (by sieving). Right hand graphs depict sediments dry sieved to $45 \mu \mathrm{m}$. Vertical line indicates $63 \mu \mathrm{m}$ and number in italics indicates the percentage of material finer than this.
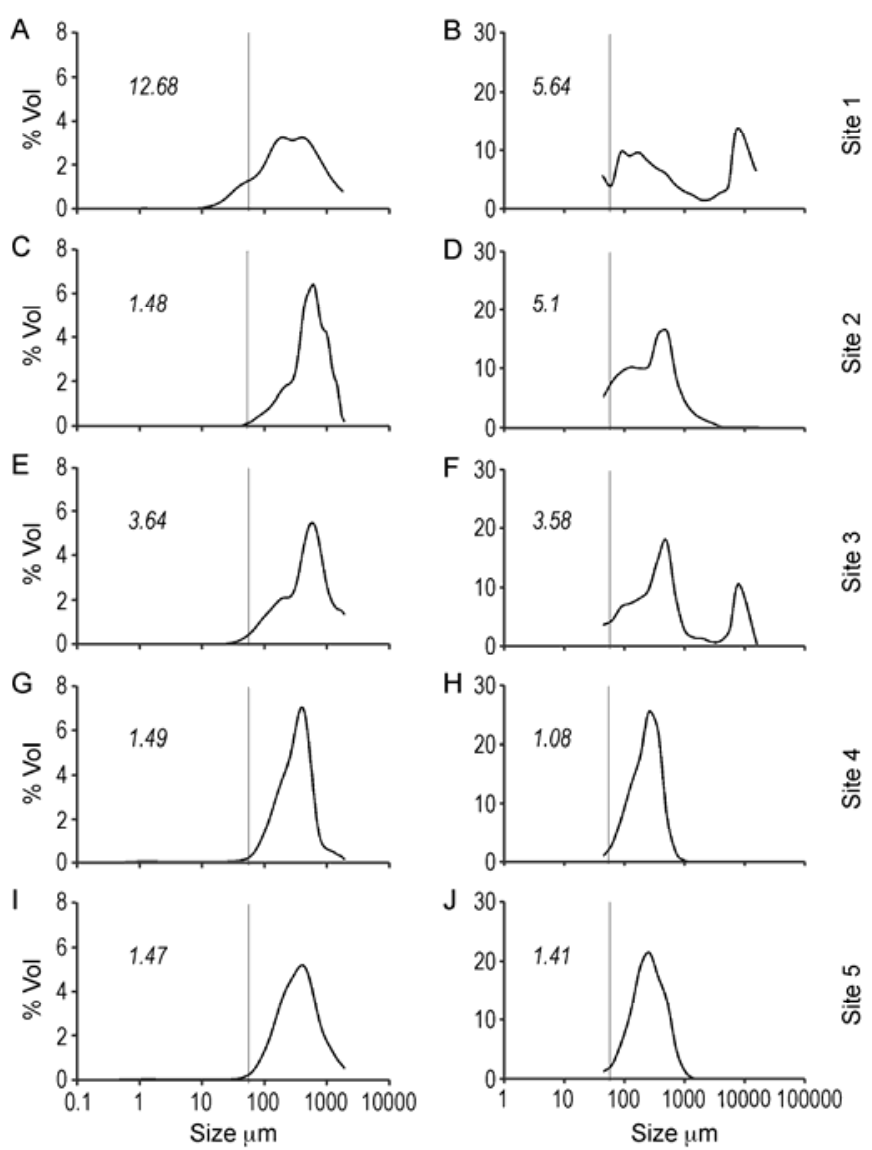
Figure 8 Relationship between mean grain size, sorting and kurtosis for surface sediment fraction $<1.4 \mathrm{~mm}$ diameter (by sieving).
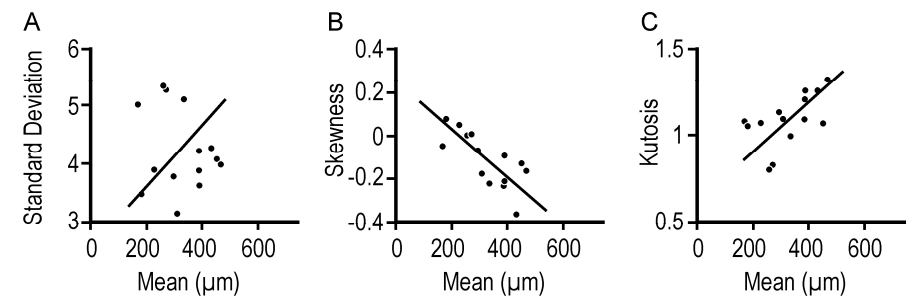
Figure 9 Time-averaged wind speeds (fractional speed-up ratios) down valley at three sampling heights for winds approaching at (a) 40$50^{\circ}$ and (b) $100-110^{\circ}$. N.B. wind direction is from left to right.
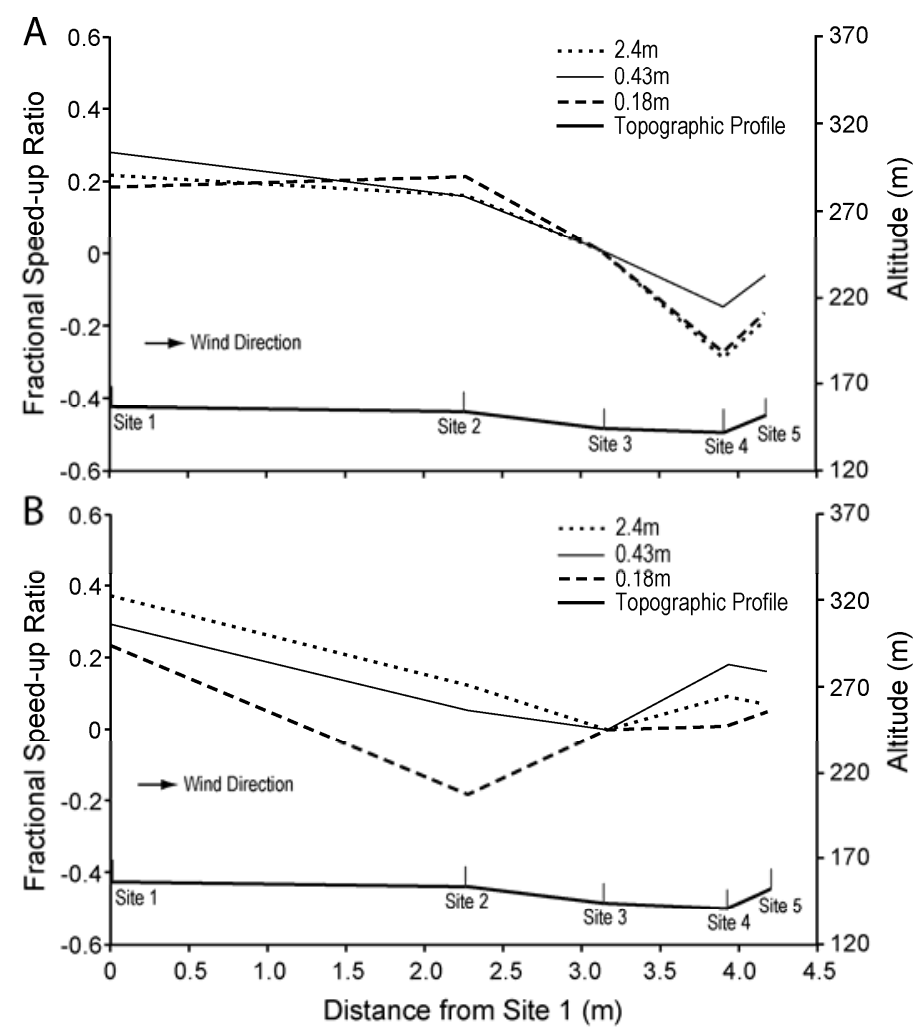
Figure 10 Sediment load trapped in BSNE samplers for days 1-7 and days 8-65. At each site, trap two is mounted at $1.5 \mathrm{~m}$ above the surface, trap three at $0.85 \mathrm{~m}$, trap four at $0.43 \mathrm{~m}$ and trap five at $0.18 \mathrm{~m}$.

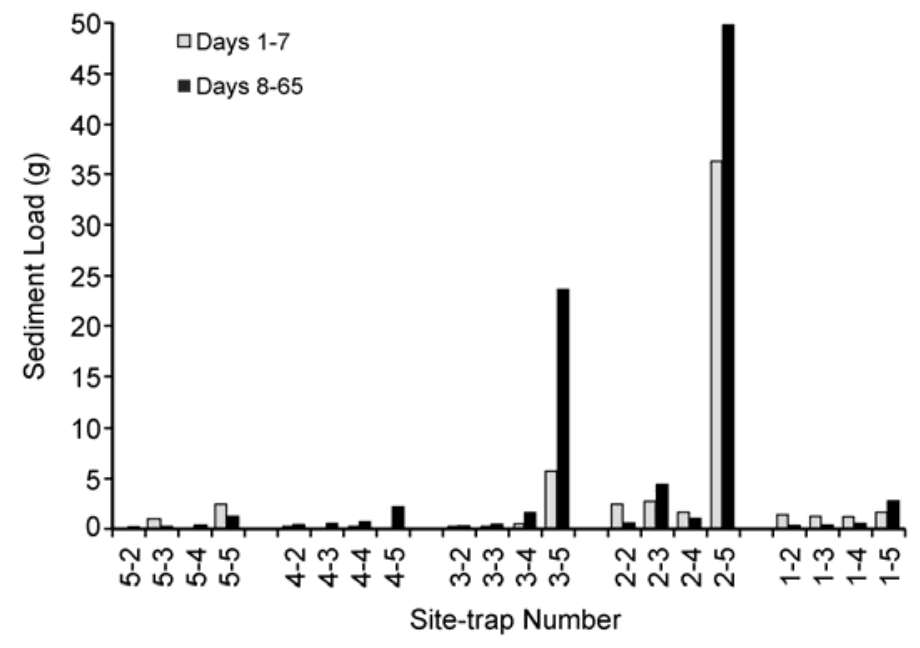


Figure 11 Particle-size distributions for trapped sediments at each site for days 1-7 and 8-65. In each case the distribution for surface sediments $(<1.4 \mathrm{~mm})$ is also plotted for comparison. Panel $\mathrm{K}$ shows the particle-size distribution for fluvial silt deposits. WR003 is a channel margin deposit; WR002 and WR001 are floodplain deposits.
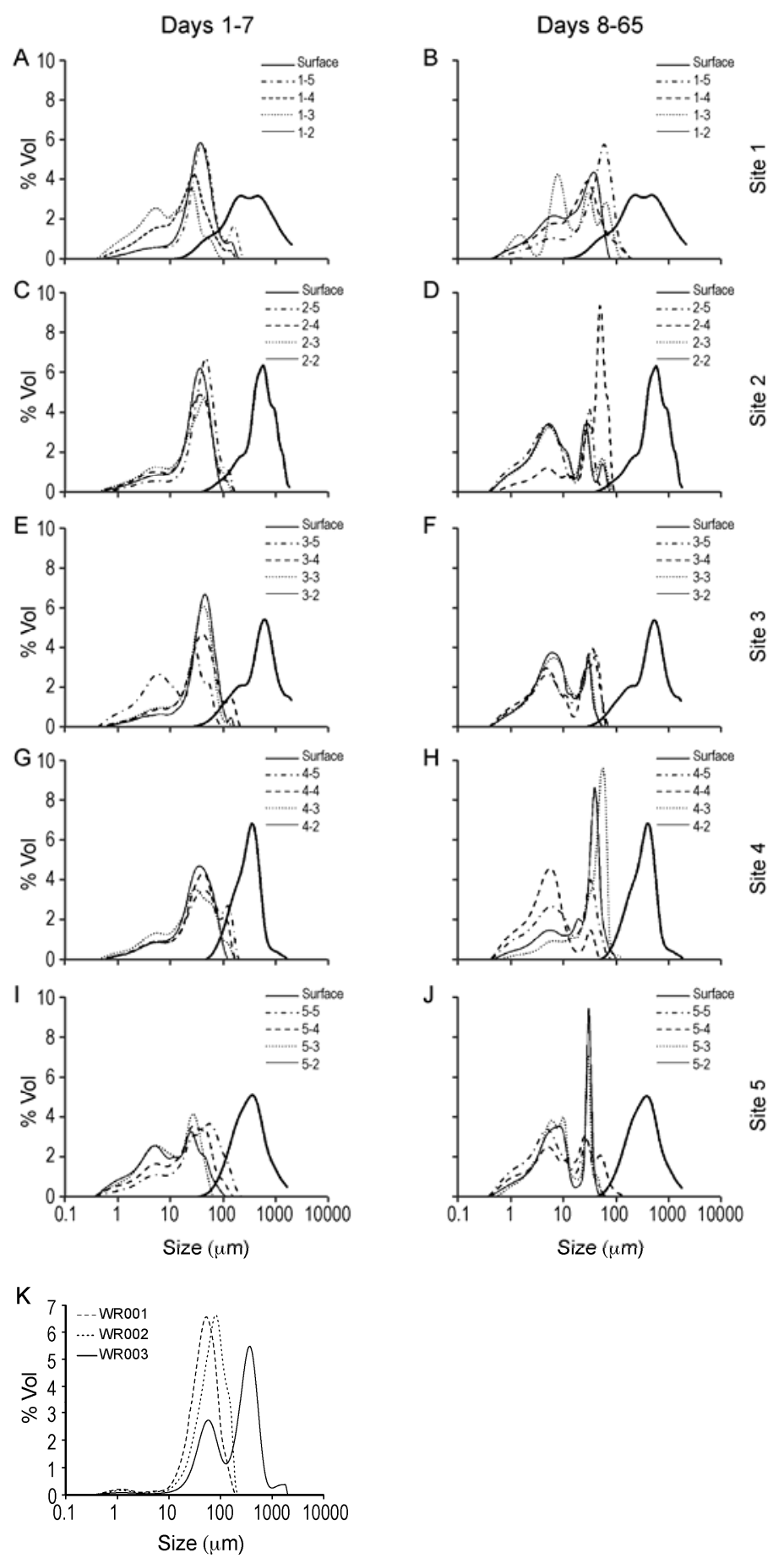
Figure 12 Fluvial sediments $270 \mathrm{~m}$ up valley from site one in a) early June 2007 clearly showing a layer of silts (pale colour) deposited on top of fluvial gravels and b) mid-August when most of the siltsized material has been deflated and a lag deposit has formed limiting further aeolian entrainment.
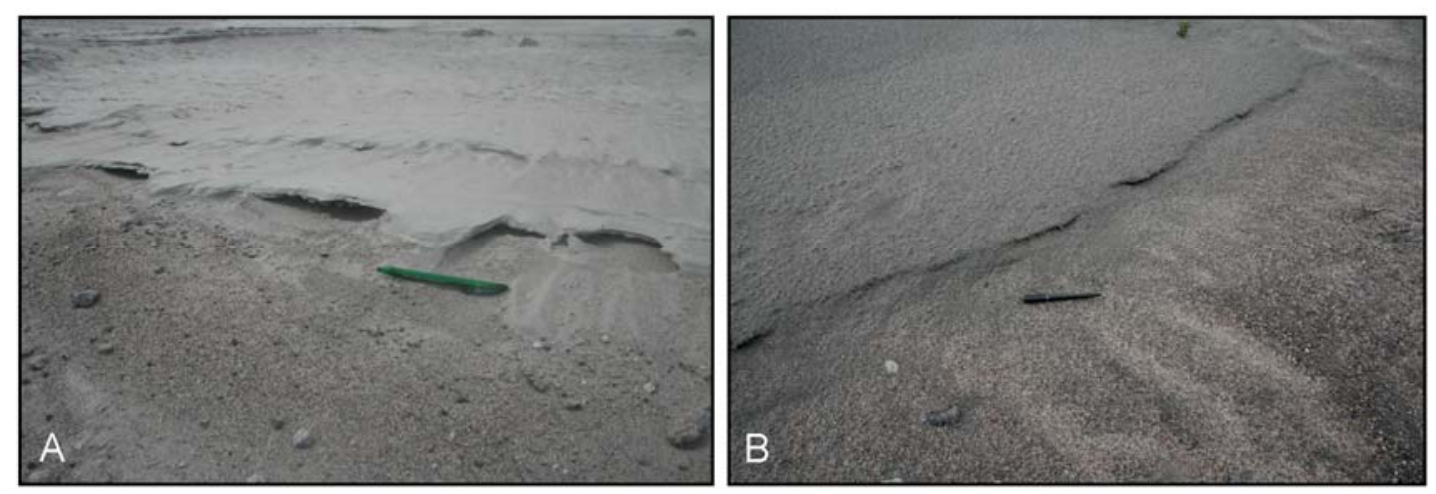